Mictial W. Sole
Secretary

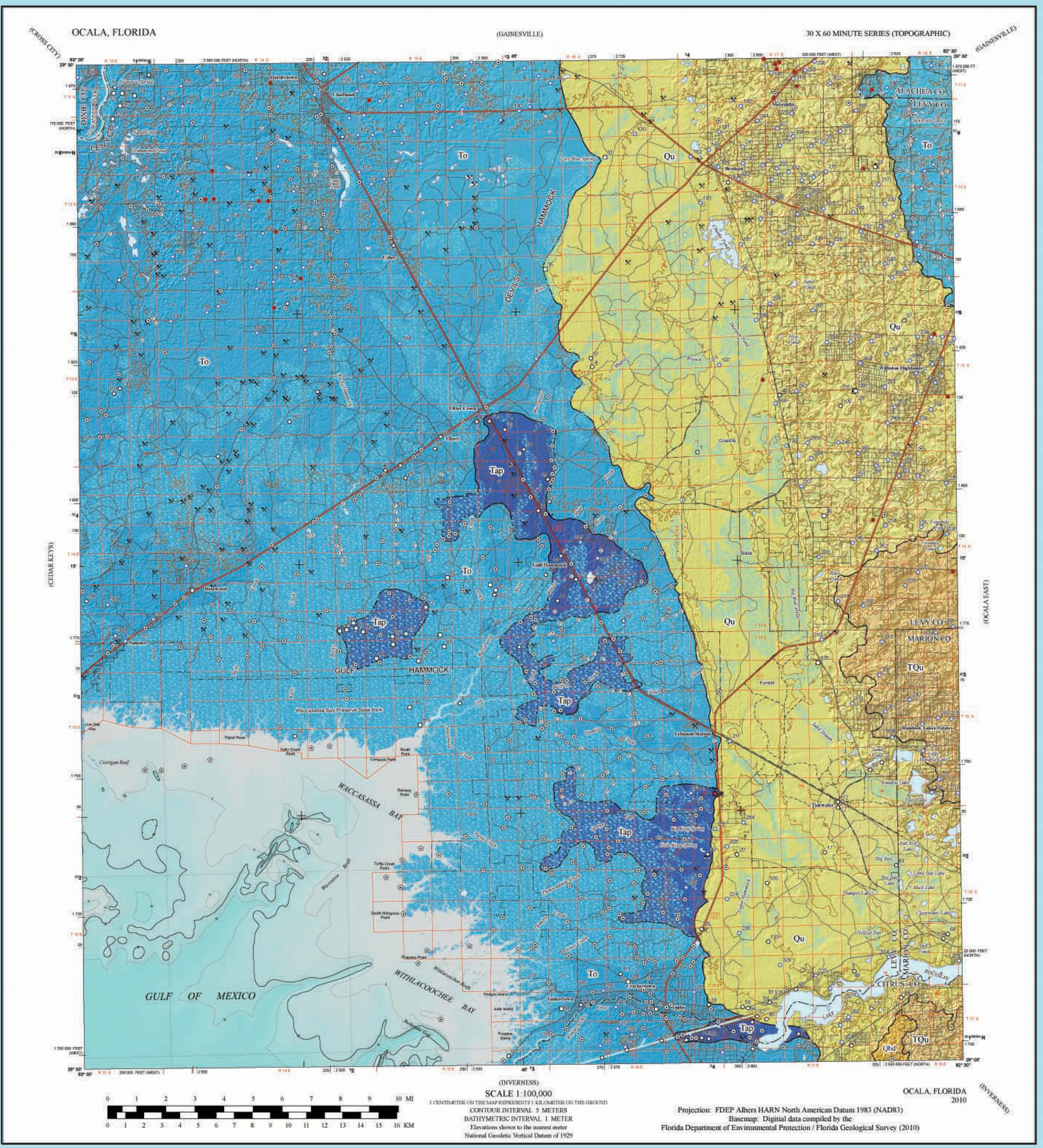

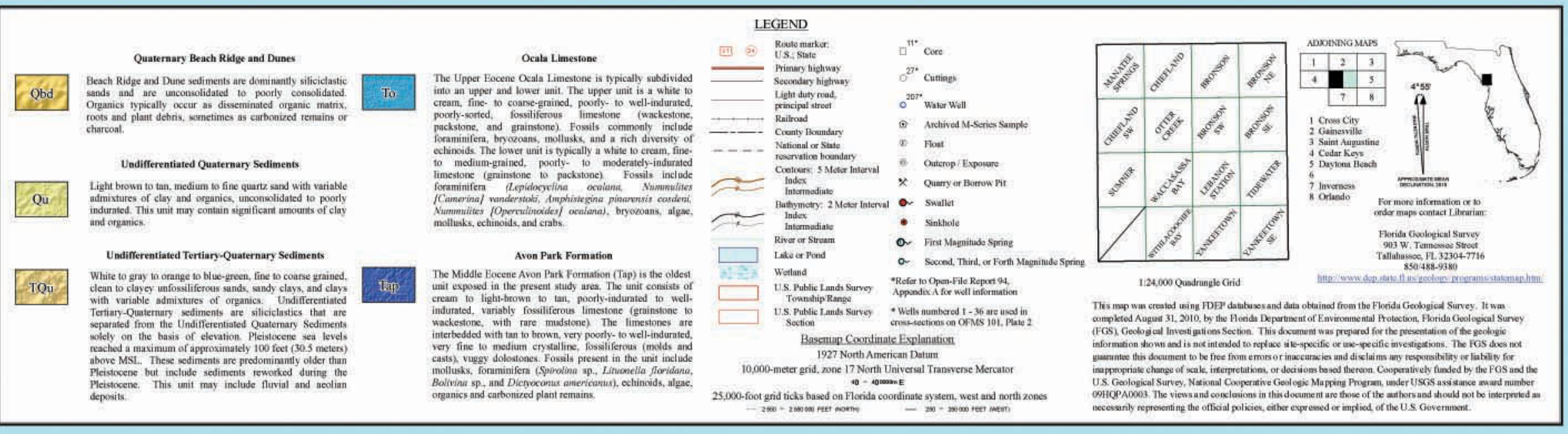




\begin{tabular}{|c|c|c|}
\hline $\begin{array}{l}\text { Michael W. Sole } \\
\text { Secretary }\end{array}$ & $\begin{array}{c}\text { OPEN-FILE MAP SERIES 101, Plate } 2 \\
\text { GEOLOGIC CROSS-SECTIONS FOR THE WESTERN PORTION OF THE USGS } \\
\text { OCALA } 30 \text { X 60 MINUTE QUADRANGLE, NORTH-CENTRAL FLORIDA } \\
2010 \\
\text { BY } \\
\text { RICHARD C. GREEN,P.G. HI776, CHRISTOPHER P. WILLIAMS, P.G, ANDREW D. FLOR } \\
\text { DAVID T.PAUL, P. G.., CLINTON KROMHOUT, P.G. AND THOMAS M. SCOTT. P.G. }\end{array}$ & $\begin{array}{l}\text { Jonanthum D. Arnhur } \\
\text { Stute Geologist and Dirctor }\end{array}$ \\
\hline
\end{tabular}
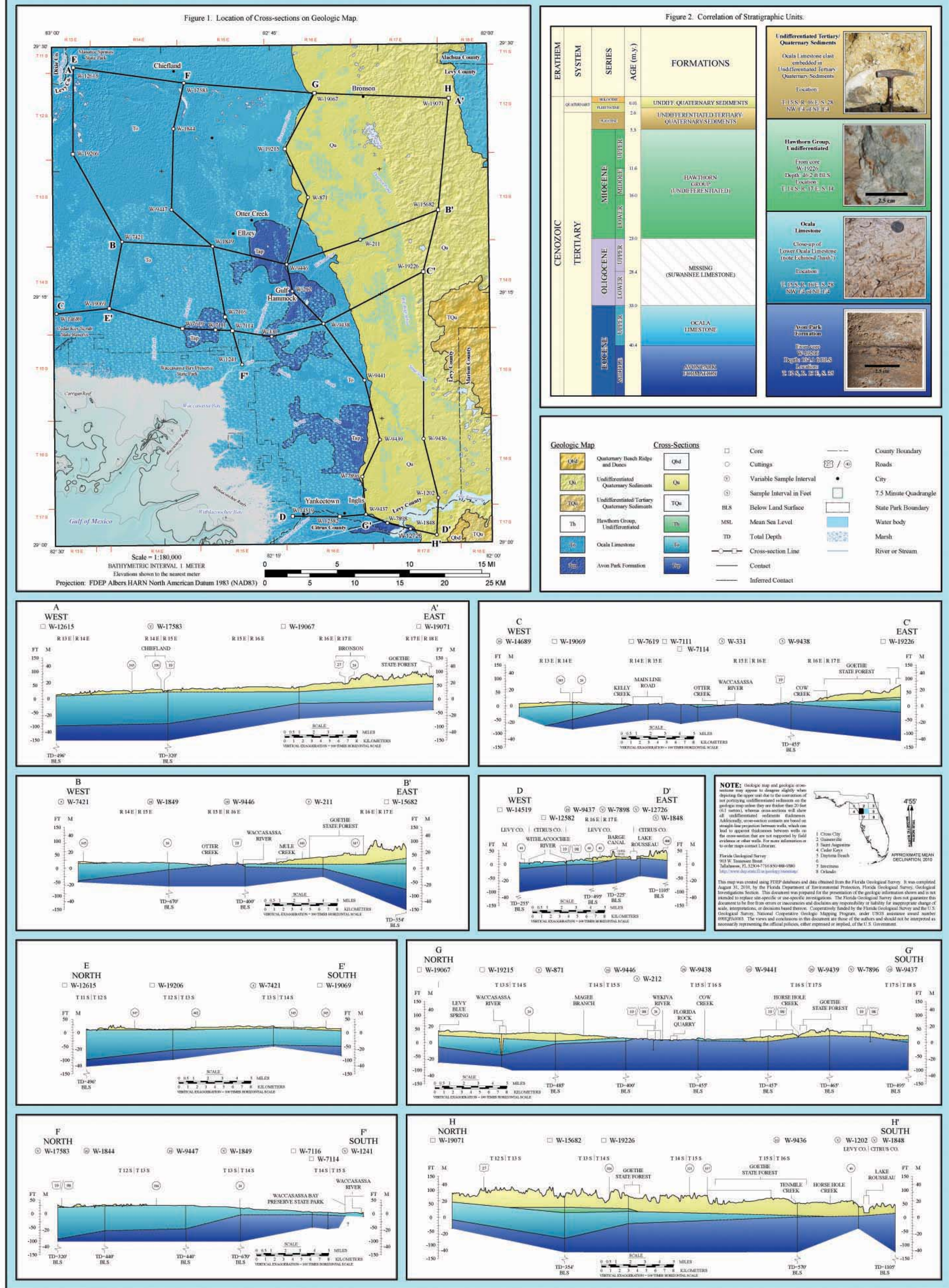

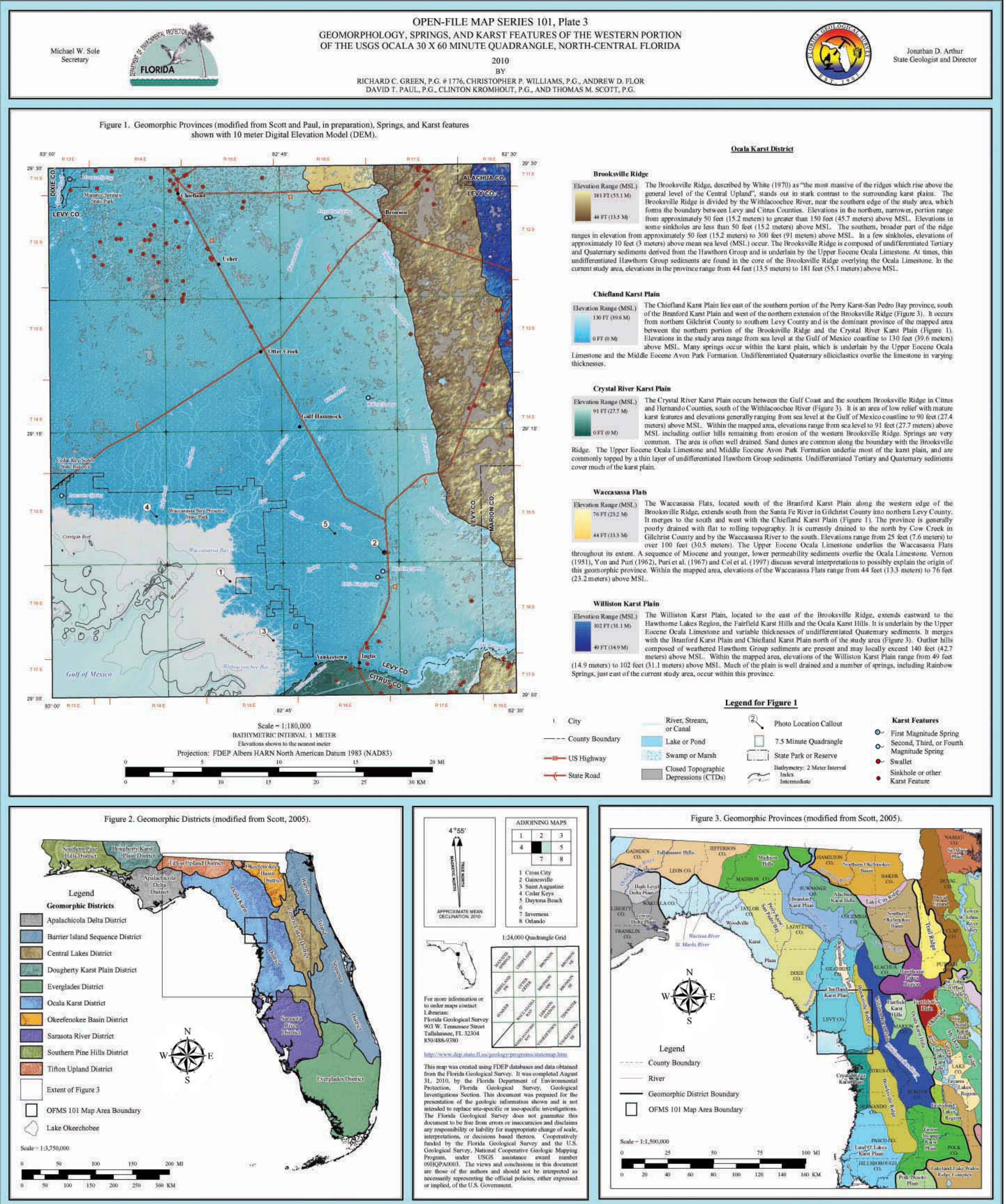

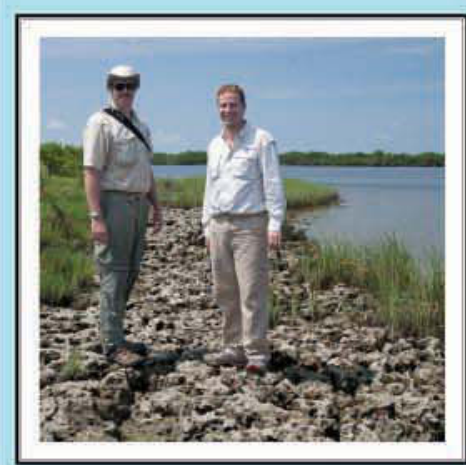

Photo I. Richard Green and Christopher Williams standing

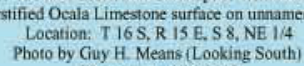

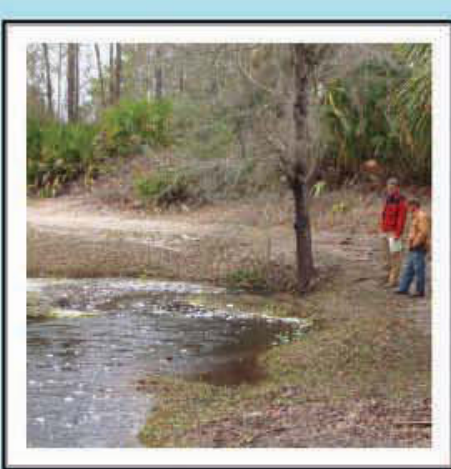

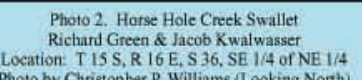
Chrissopher P. Williams L Looking Nort
Date taken: $3 / 172010$

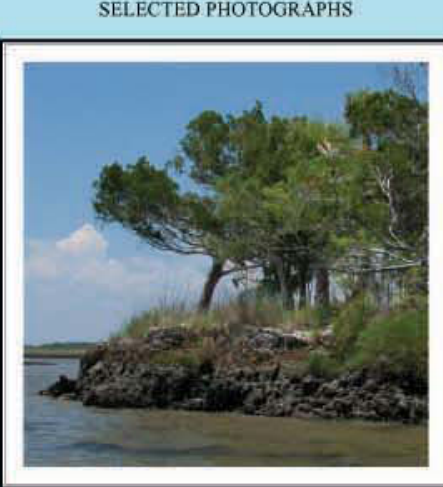

Photo 3. Ocath Limestone exposed
on unnamed istand, Withincoochee Bay. Photo by Richard C. . Green
Date taken: 61172010

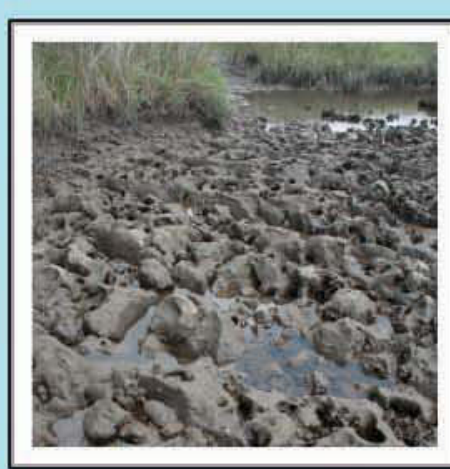

Photo 4. Heavily karatified Ocala Limestone surfine

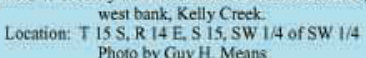
Phoro by Guy HMeans
Dale tiken: 6152010

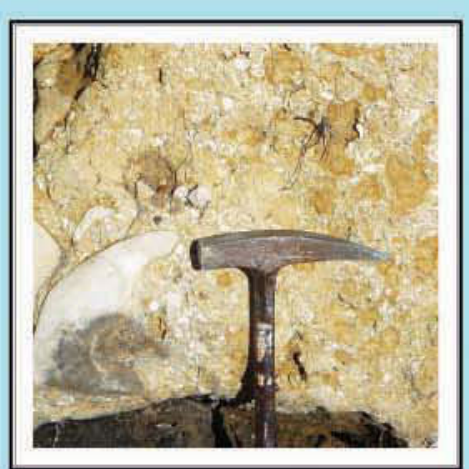

Photo 5. Rip-up chast of Ocala L Limessone emberd
within shelly Pleistocene seciments See Open-File Report 94, p. 16 for explanation.
Location T IIS S, R $16 \mathrm{E}$. S28, SW 1/4 of NE 1/4 


\section{STATE OF FLORIDA}

\section{DEPARTMENT OF ENVIRONMENTAL PROTECTION Mimi A. Drew, Secretary}

\section{LAND AND RECREATION}

Robert G. Ballard, Deputy Secretary

FLORIDA GEOLOGICAL SURVEY

Jonathan D. Arthur, State Geologist and Director
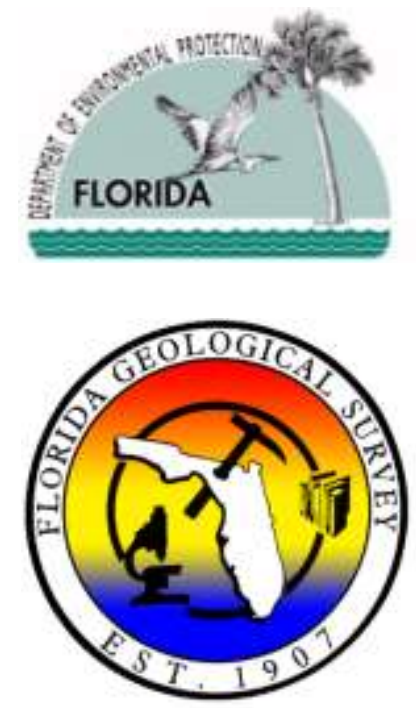

OPEN-FILE REPORT 94

Text to accompany geologic map of the western portion of the USGS Ocala $30 \times 60$ minute quadrangle, north-central Florida

By

Christopher P. Williams, Richard C. Green, Andrew D. Flor, David T. Paul, Thomas M. Scott and Clinton Kromhout

2010

ISSN (1058-1391)

This geologic map was funded in part by the USGS National Cooperative Geologic Mapping Program under assistance award number 09HQPA0003 



\section{TABLE OF CONTENTS}

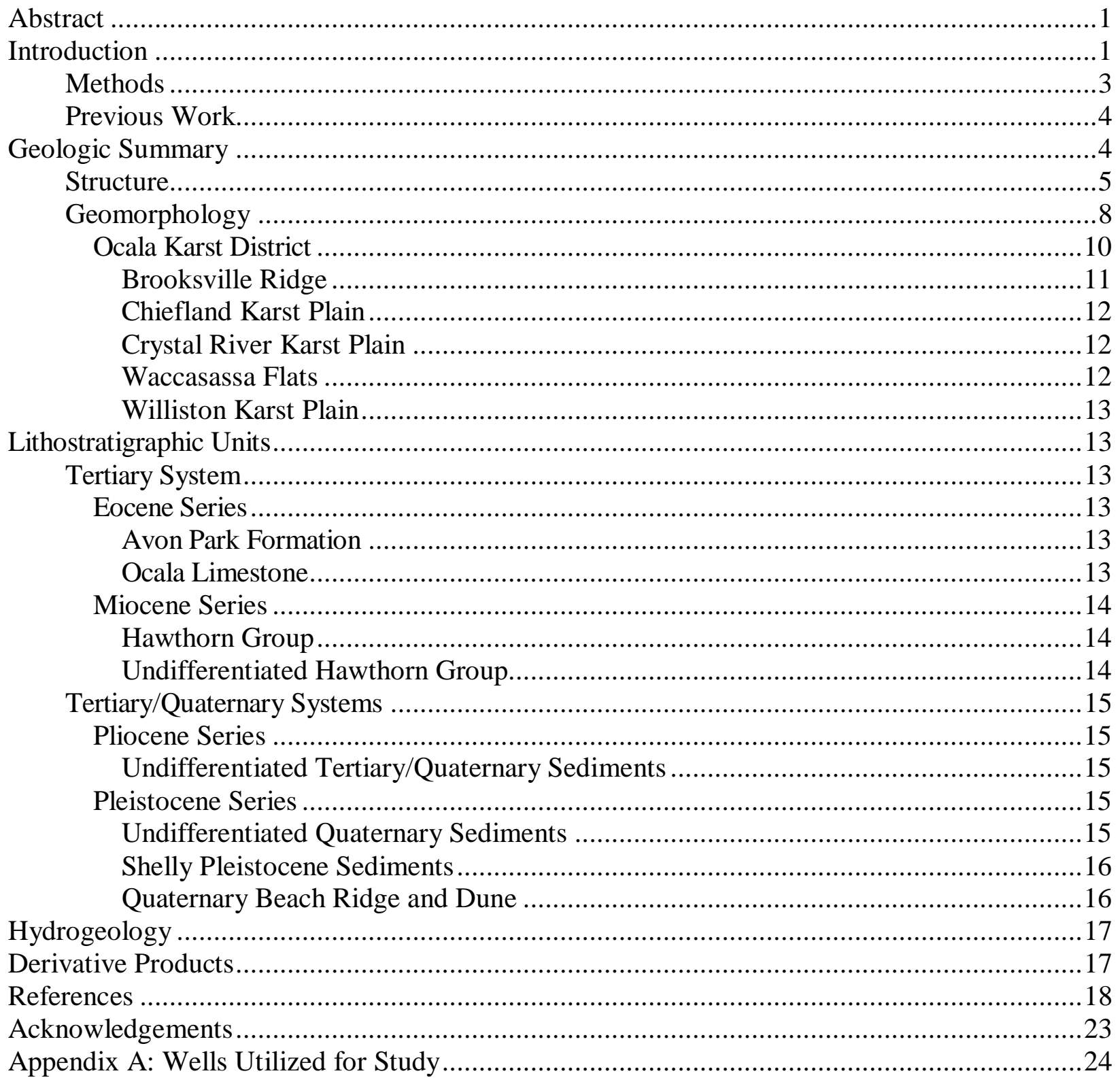

\section{LIST OF FIGURES}

Figure 1. Nearby areas mapped under the FGS STATEMAP Program. ....................................

Figure 2. Location of selected river basins, springs, swallets, and other water bodies...................6

Figure 3. Principal subsurface structures of north Florida ……................................................

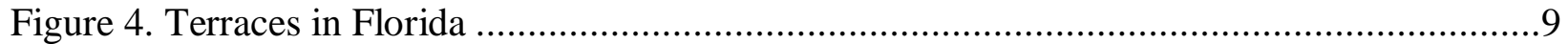





\title{
Text to accompany geologic map of the western portion of the USGS Ocala 30 x 60 minute quadrangle, north-central Florida
}

\author{
Christopher P. Williams (P.G. \#2625), Richard C. Green, P.G., Andrew D. Flor, \\ David T. Paul, P.G., Thomas M. Scott, P.G. and Clinton Kromhout, P.G.
}

\begin{abstract}
The accompanying 1:100,000 scale geologic map (Open-File Map Series 101, Plate 1) depicts the areal distribution of bedrock and surficial geologic units for the western portion of the USGS Ocala 30 x 60 minute quadrangle. The map was constructed using a combination of field mapping (at 1:24,000 scale), compilation of data from existing maps (various scales), core and cuttings analyses and descriptions, and analyses of various Geographic Information System (GIS) data sources. The resulting data were compiled in ESRI ${ }^{\circledR} \operatorname{ArcGIS}^{\circledR} \operatorname{ArcMap}^{\mathrm{TM}}$ 9.3.1 software for publication as part of the Florida Geological Survey Open-File Map Series. Mapped units range in age from Middle Eocene to Quaternary. Important resources in the mapped area include groundwater, springs, sand, clay and limestone. Numerous springs, one identified swallet (sinking stream), and other karst features are present in the study area. Understanding of geologic units, karst, springs and their interactions within the area aids land planners, environmental professionals, and citizens in making land-use decisions. Examples include designing new construction projects, siting new water supply wells and energy production facilities, siting waste management and storage facilities, locating sources of mineable resources for aggregate supply, and protection of springs, surface and groundwater quality.
\end{abstract}

Keywords: Florida, geologic map, Hawthorn Group, Ocala Limestone, Avon Park Formation, geomorphology, hydrogeology, springs, swallets, sinkholes, Floridan aquifer system, Levy County, Citrus County, Marion County, Dixie County, Alachua County, Brooksville Ridge, Waccasassa Flats.

\section{INTRODUCTION}

The Florida Geological Survey (FGS) Open-File Report (OFR) 94 accompanies OpenFile Map Series (OFMS) 101, which is comprised of three plates. Plate 1 depicts the near-surface geology of the western half of the USGS Ocala 30 x 60 minute quadrangle (U.S. Geological Survey, 1978) on a digital elevation model (DEM). Plate 2 depicts eight geologic cross-sections, a stratigraphic correlation chart, and representative photos for several of the lithologic units in the study area. Plate 3 is a geomorphology map on a DEM, showing locations of known springs, sinkholes and swallets, along with photographs of selected exposures within the study area.

The study area lies southwest of Gainesville, Florida and includes the communities of Chiefland, Bronson, Otter Creek, Gulf Hammock, Ellzey, Rosewood, Yankeetown, Crackertown and Inglis. It includes portions of Levy, Citrus, Marion, Dixie and Alachua Counties (Figure 1). It lies due south of the western portion of the USGS Gainesville $30 \times 60$ minute quadrangle, which was previously mapped under the STATEMAP program (Evans et al., 2004). Three regionally important rivers, the Withlacoochee, the Waccasassa and the Suwannee, occur in the 


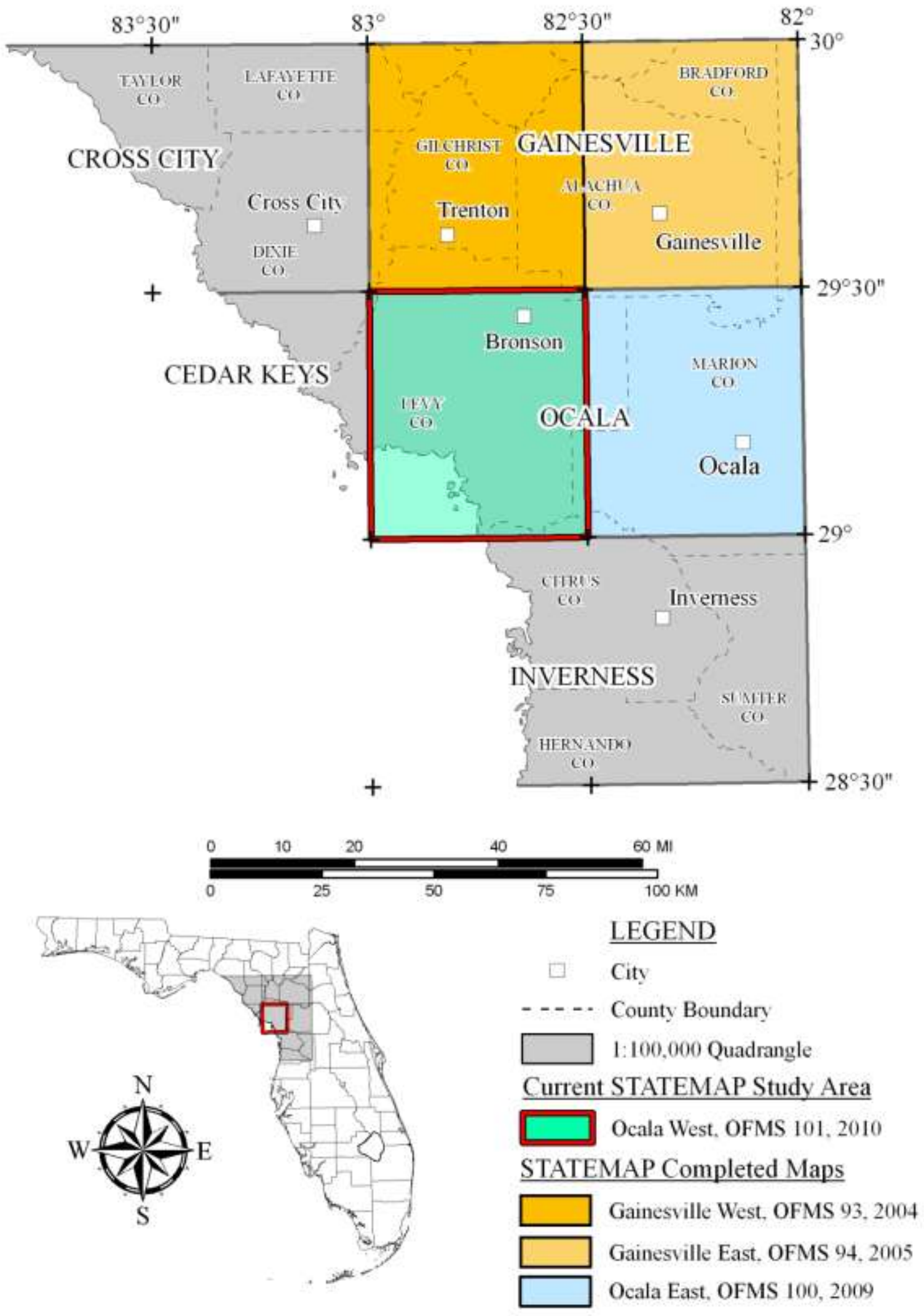

Figure 1. Nearby areas mapped under the FGS STATEMAP Program. 


\section{OPEN-FILE REPORT 94}

map area. Much of the area provides recharge to the Floridan aquifer system, the primary source of springs and drinking water in the region.

One objective for this report is to provide basic geologic information for the accompanying OFMS 101 geologic map, cross sections, and geomorphology plate. Information provided by this report and the plates in OFMS 101 reaches a diverse audience comprising professionals in geology, hydrology, engineering, environmental and urban planning, and laypersons, all of whom have varying levels of geologic knowledge. The map can help users identify and interpret geologic features which impact activities related to groundwater quality and quantity, location of mineral resources, land-use planning and construction project design. Applied uses of the maps and data in this report include: 1) identifying potential new mineral resources, 2) characterizing zones of potential aquifer recharge and confinement, 3) aiding watermanagement decisions on groundwater flow and usage, 4) providing information on aquifer vulnerability to potential pollution, 5) ecosystem, wetlands, and environmental characterization and 6) recreational uses.

\section{Methods}

Mapping efforts consisted of: 1) reviewing and compiling existing geologic literature and data, 2) mapping geologic units in the field at 1:24,000 scale using standard techniques, 3) analyses of existing core and cuttings samples, 4) new core drilling, 5) collecting and describing outcrop samples and 6) preparing a geologic map, geological cross-sections and geomorphic map of the area. Field work, performed during the fall of 2009 through the summer of 2010, consisted of sampling and describing numerous outcrops, and river and quarry exposures. One hundred eighty new samples of geologic material were added to the FGS surface-sample archives (MSeries) and seven cores (948 ft total) were drilled. An additional 86 archived M-Series samples and over 200 outcrops and exposures were also examined during this project. All data, including over 200 wells from the study area and bordering 7.5 minute quadrangles, were compiled and analyzed by the authors. Appendix A includes both FGS wells within the study area boundary, other than several in the Manatee Springs quadrangle that were not included due to map labeling density, and Water Management District well data points with top of limestone/dolostone rock information. An interpolated top of rock surface was developed using kriging along with the DEM to generate an overburden thickness model. The map and accompanying plates were developed in ESRI $^{\circledR}$ ArcGIS $^{\circledR}$ ArcMap $^{\text {TM }}$ 9.3.1 software for publication as part of the FGS OFMS.

Much of the study area is blanketed by a veneer of undifferentiated Tertiary and Quaternary sediments and soils. For this reason, and in keeping with geologic mapping practices developed by Scott et al. (2001), the authors have adopted the policy of mapping the first named geologic unit within $20 \mathrm{ft}(6.1 \mathrm{~m})$ of the surface. If undifferentiated Tertiary/Quaternary (TQu) or undifferentiated Quaternary $(\mathrm{Qu})$ sediments attain a thickness greater than $20 \mathrm{ft}(6.1 \mathrm{~m})$, then they appear as the mapped unit. If these undifferentiated sediments are less than $20 \mathrm{ft}(6.1 \mathrm{~m})$ thick, then the underlying lithostratigraphic unit appears on the map.

The region is generally vegetated, and public access in parts of the mapped area is hindered by the presence of numerous farms, ranches and privately owned land. Much of the central portion of the study area is owned by Plum Creek Timber Company, Inc., and permission to access the area for drilling operations was denied by the company; therefore the authors had to

rely on existing well and core data in this area. Fieldwork access was typically limited to public 
roads, State-owned lands, Levy County-owned lands, and Suwannee River Water Management District and Southwest Florida Water Management District-owned lands. The authors were also allowed reconnaissance access to Plum Creek Timber Company, Inc. lands.

\section{Previous Work}

The current study builds on many previous geologic investigations in and around the present map area which were useful in preparing this report. Preliminary county geologic maps for Alachua (Scott and Campbell, 1992), Citrus (Campbell and Scott, 1992), Dixie (Campbell, 1992a), Levy (Campbell, 1992b) and Marion (Scott, 1992) Counties at scales of 1:126,720 were previously published by the FGS. However, each of these OFMS geologic maps were constructed in an average time-frame of two weeks utilizing selected in-house geologic data with little-to-no extra field work. Although these maps provided a starting point for the detailed geologic mapping undertaken for this project, significant refinement of prior geologic maps was possible as a result of this project. A statewide geologic map (Scott et al., 2001) was published by the FGS in digital format and provided much of the base map material. A structure-contour map of the top of the Floridan aquifer system (Allison et al., 1995), and an isopach map of the Hawthorn Group in the region (Groszos and Rupert, 1992) also proved useful.

This study benefited greatly from the work performed during geologic mapping in the eastern portion of the USGS Gainesville $30 \times 60$ minute quadrangle (Green et al., 2005), the western portion of the USGS Gainesville 30 x 60 minute quadrangle (Evans et al., 2004) and builds upon the work of Green et al., (2009a; 2009b) for the eastern portion of the USGS Ocala 30 x 60 minute quadrangle (Figure 1). Many of the field relationships and stratigraphic problems were worked out during those projects and data gathered during those projects proved invaluable to the completion of this project.

\section{GEOLOGIC SUMMARY}

The near surface geology of the western portion of the USGS $30 \times 60$ minute Ocala quadrangle is composed of a complex mixture of Middle Eocene to Quaternary carbonate and siliciclastic sediments. A combination of factors, including fluvio-deltaic deposition, marine deposition, dissolution of underlying carbonates, erosion of sediments as a result of eustatic changes in sea level and structural features, have influenced the geology of the study area.

Distinction between the Middle Eocene Avon Park Formation and the unconformably overlying unit, the Upper Eocene Ocala Limestone, is at times difficult in the study area. Dolomitization of the Avon Park Formation and common recrystallization of the lowermost Ocala Limestone has significantly altered the original rock lithology and fabric. Fossil indicators are only somewhat helpful because the latest deposits of the Avon Park Formation and the earliest deposits of the Ocala Limestone are both bank assemblages, consistent with deposition in a shallow-water limestone bank or plateau, not unlike the present day Bahama Bank (Bryan, 2004). Karst development on the surface of the Avon Park Formation and later the Ocala Limestone, in addition to regional erosion over the Ocala Platform, has left an undulatory contact that does not allow clear definition of regional outcrops based upon elevation. A modern analog is evident along the Waccasassa Bay and Withlacoochee Bay shorelines where modern islands of Ocala Limestone with elevations rarely more than $5 \mathrm{ft}(1.5 \mathrm{~m})$ above MSL exist in shallow flats where water depths are typically less than $3 \mathrm{ft}(0.9 \mathrm{~m})$ (OFMS 101; Plate 3, Photos 1 and 3). 


\section{OPEN-FILE REPORT 94}

Much of the western portion of the Ocala quadrangle is located within the Waccasassa River basin with parts in the Lower Suwannee River, Oklawaha River, Crystal River to St. Petersburg and Withlacoochee River South basins (Figure 2). Within the study area, these rivers and their tributaries contain several documented springs including one first magnitude spring, Manatee Spring (Scott et al., 2004). A first magnitude spring is defined as having a minimum average flow of 100 cubic feet per second, or 64.6 million gallons per day (Copeland, 2003). Many of these springs have shown significant increases in pollutants in the last few decades, particularly nitrate (Phelps, 1994; Phelps, 2004; Jones et al., 1996; Scott et al., 2002; Upchurch et al., 2004). Detailed geologic mapping of lithostratigraphic units in this area provides critical data needed for future assessments of the vulnerability of the aquifer systems and springs to contamination. The recharge areas for many springs are located within and nearby the current study area. Understanding the surficial geology of the map area is a key factor in developing management and protection plans, not only for the springs, but for the unconfined portions of the Floridan aquifer system.

\section{Structure}

Several structural variables have affected the geology of the region (Figure 3). The Peninsular Arch, a structurally high area which affected deposition from the Cretaceous to the early Cenozoic, is the dominant subsurface feature of the Florida peninsula (Applin and Applin, 1944; Applin, 1951; Puri and Vernon, 1964; Williams et al., 1977; Schmidt, 1984; Miller, 1986; Scott, 1997). The axis of the Peninsular Arch, which lies primarily to the east of the study area, extends from southeastern Georgia to the vicinity of Lake Okeechobee in southern Florida in a general northwest to southeast trend. The crest of the arch passes beneath Alachua County northeast of the study area and is highest in Union and Baker Counties north of the study area. The arch was a topographic high during most of the Cretaceous Period and had Upper Cretaceous sediments deposited upon it (Applin, 1951). It formed a relatively stable base for Eocene carbonate deposition (Williams et al., 1977). The arch did not affect mid-Tertiary to Holocene sediment deposition (Williams et al., 1977; Scott, 1997).

The Ocala Platform is the most prominent structure affecting the near surface depositional and post-depositional environments within the map area. Hopkins (1920) originally named this feature the Ocala Uplift. Vernon (1951) described the Ocala Uplift as a gentle flexure developed in Tertiary sediments with a northwest-southeast trending crest. Because there is continuing uncertainty about the origin of this feature, Scott (1988) used the term Ocala Platform, rather than Ocala Uplift or Ocala Arch, since it does not have a structural connotation.

The Ocala Platform, which underlies the current study area, influenced late Tertiary sediment deposition. Miocene sediments of the Hawthorn Group are thought to have been deposited across the platform (Scott, 1981a; Scott, 1988; Scott, 1991a). Post-Miocene erosion has removed sediments of the Hawthorn Group from much of the crest of the Ocala Platform, exposing Eocene and Oligocene carbonates (Cooke, 1945; Espenshade and Spencer, 1963; Scott, 1981b). This is evident throughout much of the eastern portion of the map area (OFMS 101; Plate 1). Undifferentiated sediments, thickest over the eastern portion of the study area, have subsequently been deposited on the exposed Eocene carbonates within the map area. These consist of residual clays, sands, and aeolian sands deposited during the Pliocene to Holocene (Scott, 1997). 


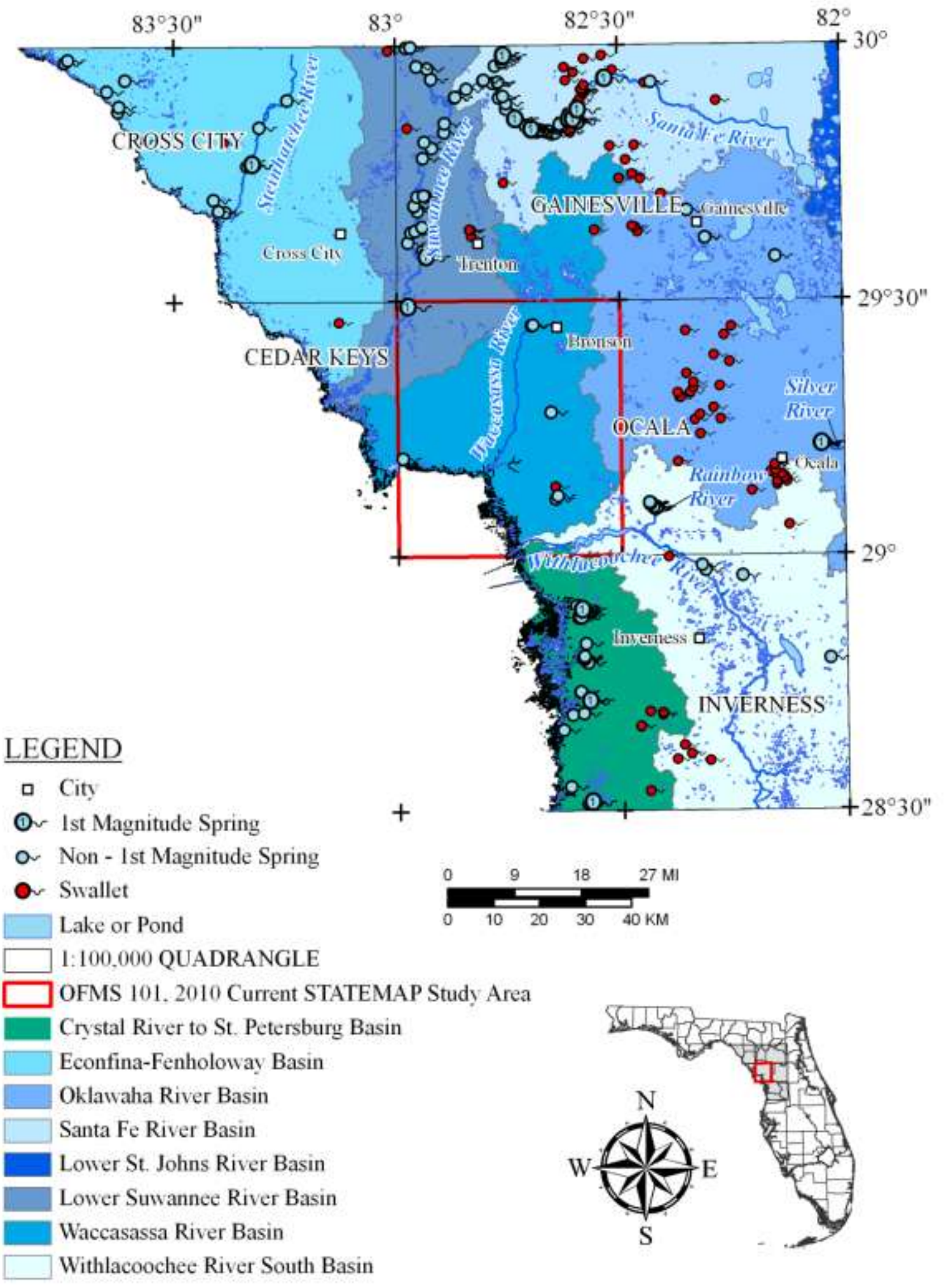

Figure 2. Location of selected river basins, springs, swallets, and other water bodies. 


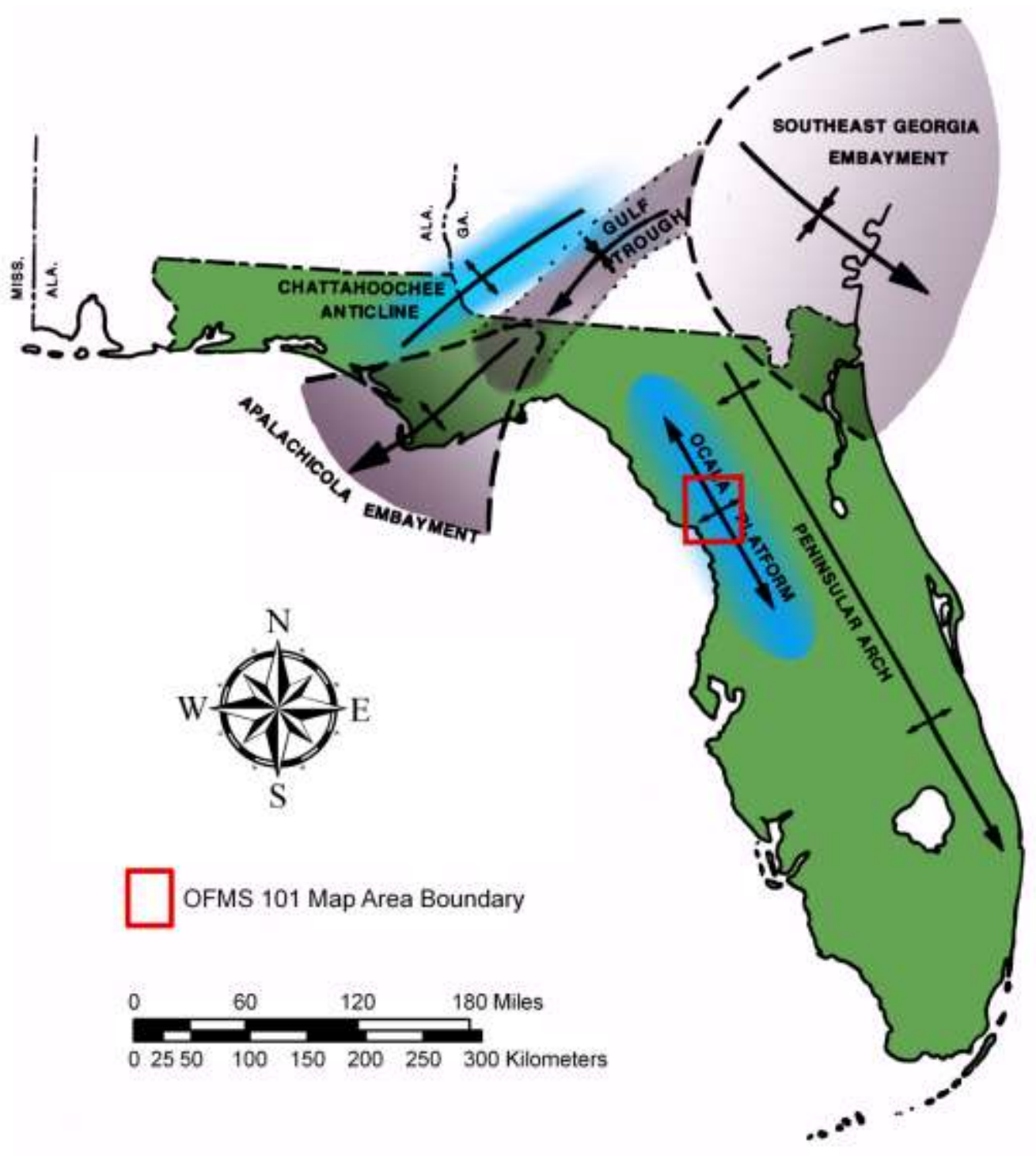

Figure 3. Principal subsurface structures of north Florida (modified from Puri and Vernon, 1964 and Schmidt, 1984).

Vernon (1951), utilizing aerial photographs, mapped fracture patterns throughout northern peninsular Florida. Regionally, these fractures generally trend parallel to the axis of the Ocala Platform in a northwest-southeast orientation. A secondary system of fractures intersects these primary fractures at high angles in a northeast-southwest trend (Vernon, 1951; see p. 47-52 for discussion of fractures). Orientation of stream meanders along portions of the Withlacoochee River suggests that these fracture patterns may be a controlling factor in stream location. 
Vernon (1951) also discussed the occurrence of faults in part of the Florida peninsula. He attributed the origin of the faults to his postulated uplift of the Ocala Platform (his Ocala Uplift). Although he described the occurrence and surface-strike orientation of the faults, there was no discussion of the dip of the faults. Vernon did mention that his postulated faults were very steeply inclined. Vernon (1951) also mentioned seeing slickensides and grabens in quarries in the study area. Similar features have been observed by several of the authors of this publication while doing fieldwork in the region. It is believed that these are related to karst collapse and localized block movement within the karst feature, not to faulting as Vernon (1951) suggested. When a cover collapse sinkhole forms, large blocks may move downward along fractures created by the collapse and create localized slickensides which are not related to structural faulting. Additionally, numerous wells that Vernon (1951) used for cross-sections, which depicted faults in his report, were investigated for OFR 93 (Green et al., 2009b) and several were deemed to be karst features. For example, W-1198 (see Vernon, 1951; Figure 14), appears to be karst infill. Karst features in the study area are very common (OFMS 101; Plate 3, Photos 2 and 4).

A secondary critique of the faulting described by Vernon (1951) is the fact that many of the purported faults are actually offsets between biozonations within a formation, such as the Avon Park Formation, or between members of what Vernon (1951) called the Moodys Branch Formation (now Ocala Limestone; Puri, (1957), Scott, (1991b)). Through analysis and interpretation of hundreds of wells in the USGS Ocala 30 x 60 minute quadrangle, the present authors recognize that there is great variability in the Ocala Limestone and the Avon Park Formation that is in large part related to original environments of deposition. Therefore, any faulting inferred based upon differences within the Avon Park Formation and Ocala Limestone are more likely variations due to environmental facies, not that these formations have distinct, identical, horizontal beds that are continuous and contiguous throughout the entire formation. It has already been discussed that the unconformable contact of the Avon Park Formation and the Ocala Limestone is not a planar surface, but formed on a topographically variable karstified surface. Thus, adjacent localities where Ocala Limestone and Avon Park Formation are at the same elevation do not demand a structural solution.

\section{Geomorphology}

Several relict Neogene coastal terraces, which developed as a result of fluctuating sea levels, have been documented in the study area. Healy (1975) recognized six possible marine terraces within the study area (Figure 4) based upon elevation: the Silver Bluff terrace between 1 and $10 \mathrm{ft}(0.3$ and $3 \mathrm{~m})$ above mean sea-level (MSL), the Pamlico terrace from 10 to $25 \mathrm{ft}$ (3 to $7.6 \mathrm{~m}$ ) above MSL, the Talbot terrace at elevations between 25 and $42 \mathrm{ft}(7.6$ and $12.8 \mathrm{~m})$ above MSL, the Penholoway terrace at elevations between 42 and $70 \mathrm{ft}$ (12.8 and $21.3 \mathrm{~m}$ ) above MSL, the Wicomico terrace at elevations of 70 to $100 \mathrm{ft}(21.3$ to $30.5 \mathrm{~m})$ above MSL and the Sunderland/Okefenokee terrace at elevations between 100 and $170 \mathrm{ft}$ (30.5 and $51.8 \mathrm{~m})$. Detailed discussions and correlations of these marine terraces and relict shorelines have been attempted by many authors, including Matson and Sanford (1913), Cooke (1931, 1939), Flint (1940, 1971), MacNeil (1950), Alt and Brooks (1965), Pirkle et al. (1970) and Healy (1975).

There are at least three relict shoreline features observed in eastern to southeastern Levy County, within the current study area, and they are visible on both Plate 1 and Plate 3, Figure 1 of OFMS 101. The westernmost of these features has a base elevation around $20 \mathrm{ft}(6.1 \mathrm{~m})$. The 


\section{OPEN-FILE REPORT 94}

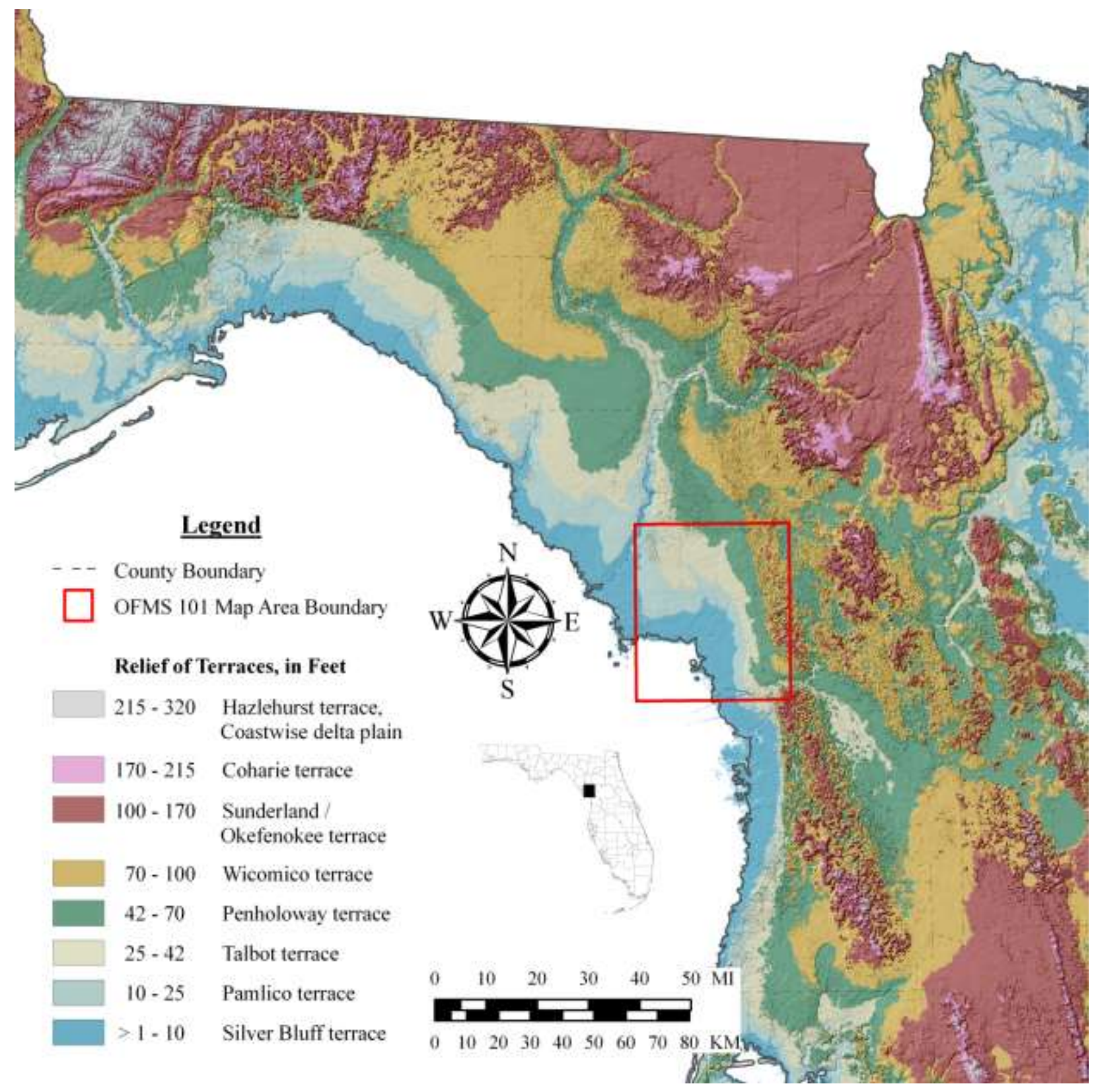

Figure 4. Terraces in Florida (after Healy, 1975).

elevations at the top of the ridge are predominantly 30-35 $\mathrm{ft}$ (9.1-10.7 $\mathrm{m}$ ) with some highs up to $39 \mathrm{ft}(11.9 \mathrm{~m})$. This ridge may actually be two ridges as there is a zone of modified trellis drainage with directions of flow parallel to ridge orientation. Elevations to the east of this first relict shoreline decrease to about $35 \mathrm{ft}(10.7 \mathrm{~m})$ with some small, persistent swamps. Overall, the elevations then slowly rise to the east to about $45 \mathrm{ft}(13.7 \mathrm{~m})$ at the base of the second ridge feature. The second ridge only has dominant highs from $50-55 \mathrm{ft}(15.2-16.8 \mathrm{~m})$, but the topography to the east of the ridge returns to about $45 \mathrm{ft}(13.7 \mathrm{~m})$. There are several extensive swamps along this trace at the western toe of the Brooksville Ridge. These swamps include 
Deerpen Pond, Big Wolf Arbor and Sand Slough, and according to White (1970) are interpreted to exist where lagoons once occurred between this ridge and the Brooksville Ridge. The western toe of the Brooksville Ridge also appears to be a relict shoreline with a base elevation of $50 \mathrm{ft}$ $(15.2 \mathrm{~m})$. It has much more headward erosion than the smaller features to the west. Therefore, its western margin is more dissected by stream drainages. Elevations to the east rise rapidly to 75 $100 \mathrm{ft}(22.9-30.5 \mathrm{~m})$.

Based upon the nomenclature of Healy (1975), the lowest, westernmost of the aforementioned ridges would relate to the Pamlico terrace due to its base elevation of $20 \mathrm{ft}(6.1$ $\mathrm{m})$. The second ridge has a base elevation that correlates to the Penholoway. However, the terrace developed to the west of this ridge has elevations that vary from 35-45 ft (10.7-13.7 m). These elevations overlap between the Talbot and Penholoway terraces. White (1970) presumes this to be a Pamlico terrace and the ridge as a barrier island positioned between the Gulf of Mexico and the paleoshoreline of the Brooksville Ridge, but the timing seems unlikely given the terrace elevations. The terrace associated with the Brooksville Ridge is best related to the Penholoway, but the elevations of the Brooksville Ridge suggest that it may have formed at some earlier, higher sea level and the present terrace at the western toe is a later geomorphic event that modified the western flank of the ridge. White (1970) inferred by its elevation that the Brooksville Ridge must be related to the Wicomico with sea level over $100 \mathrm{ft}(30.5 \mathrm{~m})$ above MSL. However, White (1970) also noted that the Brooksville Ridge has "suffered so much differential subsidence from solution of underlying limestone that it is difficult to correlate." Isostatic rebound initiated by carbonate dissolution further complicates tracing elevationally delineated features in Florida (Adams et al., 2010).

According to Scott et al. (in preparation), the study area is entirely within the Ocala Karst District (OFMS 101; Plate 3, Figure 2). Within the map area, the Ocala Karst District has been further subdivided topographically into five regional physiographic provinces: the Brooksville Ridge, the Chiefland Karst Plain, the Crystal River Karst Plain, Waccasassa Flats and the Williston Karst Plain.

\section{Ocala Karst District}

The Ocala Karst District encompasses a broad area from central Wakulla County in the panhandle of Florida, south to Hillsborough and Pinellas Counties in the west-central peninsula and inland to nearly the center of the peninsula (OFMS 101; Plate 3, Figures 2 and 3). Elevations within the district range from sea level along the Gulf of Mexico coast to a maximum of $300 \mathrm{ft}$ (91.4 m) above mean sea level (MSL) on the Brooksville Ridge. Within the study area, elevations range from sea level at the coastline to $181 \mathrm{ft}(55.1 \mathrm{~m})$ above MSL in the southeast portion of the map area at the northern end of the southern part of the Brooksville Ridge in Citrus County.

Carbonate sediments of the Middle Eocene Avon Park Formation and the Upper Eocene Ocala Limestone lie at or near the land surface in this district within the study area. The Ocala Karst District is dominated by dissolution sinkholes and shallow bowl-shaped depressions, producing a rolling topography. Generally, a variably permeable siliciclastic cover allows downward percolating groundwater to slowly dissolve the underlying limestone, leading to cover-collapse sinkholes and cover-subsidence features (Sinclair and Stewart, 1985). Covercollapse sinkholes form rather abruptly from the structural failure of an underlying cavern roof. An excellent example of this is at Devil's Millhopper Geological State Park, located in Alachua County northeast of the present study area (Evans et al., 2004). 


\section{OPEN-FILE REPORT 94}

Cover subsidence features generally occur in areas where sediments sag as carbonates dissolve underneath. Typically, areas such as these have shallow sinks formed by the downward movement of the siliciclastic overburden filling voids created by slow dissolution of underlying carbonates or by slow dissolution of the carbonate surface. Springs, sinking (swallets) and resurgent streams, and caverns commonly occur within the Ocala Karst District.

\section{Brooksville Ridge}

The Brooksville Ridge, described by White (1970) as "the most massive of the ridges which rise above the general level of the Central Upland", stands out in stark contrast to the surrounding karst plains. The Brooksville Ridge encompasses most of the eastern portion of the study area (OFMS 101; Plate 3, Figures 1 and 3). It is separated into two sections (northern and southern) by the Withlacoochee River, which forms the boundary between Marion and Citrus Counties. The northern portion of the Brooksville Ridge begins in Gilchrist and Alachua Counties and terminates in Levy and Marion Counties. The southern portion extends from Citrus County southward into Pasco County.

The two sections of the ridge differ in elevation, length to width ratio and underlying geology. Elevations in the northern, narrower portion of the Brooksville Ridge range from approximately $50 \mathrm{ft}(15.2 \mathrm{~m})$ to greater than $150 \mathrm{ft}(45.7 \mathrm{~m})$ above MSL. Elevations in some sinkholes are less than $50 \mathrm{ft}(15.2 \mathrm{~m})$ above MSL. The southern, broader part of the ridge ranges in elevation from approximately $50 \mathrm{ft}(15.2 \mathrm{~m})$ to more than $300 \mathrm{ft}(91 \mathrm{~m})$ above MSL. In a few sinkholes, elevations of approximately $10 \mathrm{ft}(3 \mathrm{~m})$ above MSL occur. Within the study area, elevations in this province range from $44 \mathrm{ft}(13.5 \mathrm{~m})$ to $181 \mathrm{ft}(55.1 \mathrm{~m})$.

The topography of the Brooksville Ridge displays significant variability. The northern section has low, rolling karst hills interspersed with moderately shallow sinkholes. The southern portion of the ridge becomes progressively hillier and terrain relief increases from north to south. White (1970) describes the southern ridge area as having "the most irregular surface to be found in any area of comparable size in peninsular Florida." From the vicinity of Brooksville southward, the hills are higher and more closely spaced. North of Brooksville, the hills are more widely spaced and generally have lower elevations, an indication of more mature karst. The Brooksville Ridge is well drained with wet conditions existing only in the low lying karst features. There are no springs found on the ridge.

The Upper Eocene Ocala Limestone underlies the northern portion of the Brooksville Ridge. Weathered Miocene Hawthorn Group sediments lie unconformably on the Ocala Limestone with undifferentiated Quaternary and/or Tertiary ( $Q u$ and $\mathrm{TQu}$ ) siliciclastics mantling the ridge. The southern portion of the Brooksville Ridge (which lies predominantly south-southeast of the mapped area) is more complex geologically than the northern section. The southern section of the Brooksville Ridge is only present in a small portion of the southeast corner of the mapped area (OFMS 101; Plate 3, Figures 1 and 3). The province is underlain by carbonates of the Middle Eocene Avon Park Formation and the Upper Eocene Ocala Limestone which are overlain by variable thicknesses of weathered Miocene undifferentiated Hawthorn Group (Th) sediments and undifferentiated Tertiary-Quaternary siliciclastics (TQu), Quaternary siliciclastics (Qu) or relict dunes of the Quaternary Beach Ridge and Dune (Qbd). 


\section{FLORIDA GEOLOGICAL SURVEY}

\section{Chiefland Karst Plain}

The Chiefland Karst Plain lies to the east of the southern portion of the Perry Karst-San Pedro Bay geomorphic province, south of the Branford Karst Plain and west of the northern extension of the Brooksville Ridge. It occurs from northern Gilchrist County to southern Levy County and is the predominant geomorphic province of the mapped area (OFMS 101; Plate 3, Figures 1 and 3). Elevation of the Chiefland Karst Plain in this area ranges from sea level at the Gulf of Mexico coastline to $130 \mathrm{ft}$ (39.6 m) above MSL.

This karst plain is more poorly drained than the Branford Karst Plain to the north (Evans et al., 2004). Many springs occur within this karst plain. The entire karst plain is underlain by either Upper Eocene Ocala Limestone or the Middle Eocene Avon Park Formation. Undifferentiated Quaternary siliciclastics overlie the karstified limestone in varying thicknesses.

\section{Crystal River Karst Plain}

The Crystal River Karst Plain occurs between the Gulf of Mexico coastline and the southern Brooksville Ridge in Citrus and Hernando Counties, south of the Withlacoochee River (OFMS 101; Plate 3, Figures 1 and 3). It is an area of low relief with mature karst features and most elevations ranging from sea level to $90 \mathrm{ft}(27.4 \mathrm{~m})$ above MSL. Within the mapped area, elevations range from sea level to $91 \mathrm{ft}(27.7 \mathrm{~m})$ above MSL. Karst features are usually shallow depressions. Springs are very common near the coast. The area is often well drained, becoming more poorly drained toward the coast. Sand dunes are common along the boundary with the Brooksville Ridge (OFMS 101; Plate 1).

The Upper Eocene Ocala Limestone and Middle Eocene Avon Park Formation underlie most of the karst plain, and there is commonly a thin layer of undifferentiated Hawthorn Group sediments on top of the Ocala Limestone in this part of the map area. Undifferentiated Tertiary and Quaternary siliciclastic sediments cover this karst plain in varying thicknesses.

\section{Waccasassa Flats}

The Waccasassa Flats province, north-northwest of Bronson, contains a mixed ecosystem of sand hills, pine flatwoods, small lakes, wetlands and cypress ponds (Col et al., 1997). It is characterized by flat to gently rolling terrain. The province is poorly drained and extends from the Santa Fe River in northern Gilchrist County south throughout central Gilchrist County into northern Levy County (OFMS 101; Plate 3, Figure 1). Waccasassa Flats occurs in a small area along the northern boundary of the current study area. It lies immediately west of the Brooksville Ridge and gradually merges into the Chiefland Karst Plain to the south in northern Levy County. Elevations within the current mapped area range from $44 \mathrm{ft}(13.3 \mathrm{~m})$ to $76 \mathrm{ft}(23.2 \mathrm{~m})$ above MSL.

The Upper Eocene Ocala Limestone underlies the Waccasassa Flats throughout its extent. A sequence of Miocene and younger, lower permeability sediments overlie the Ocala Limestone. Interpretations from Vernon (1951) suggest a fluvial origin with the Waccasassa Flats occupying an area that was abandoned via stream capture. Yon and Puri (1962) and Puri et al. (1967) proposed that the Waccasassa Flats formed during the Pleistocene in a low energy back barrier bay or lagoon environment. Aspects of both of these interpretations are likely true with the fluvial occurring before the coastal environment, but the timing of these events is uncertain and requires further 


\section{OPEN-FILE REPORT 94}

investigation. The Waccasassa Flats are currently drained from the north by Cow Creek in Gilchrist County and to the south in Levy County by the Waccasassa River.

\section{Williston Karst Plain}

The Williston Karst Plain, located on the eastern flank of the Brooksville Ridge, extends eastward to the Hawthorne Lakes Region, the Fairfield Karst Hills and the Ocala Karst Hills and is underlain by the Upper Eocene Ocala Limestone (OFMS 101; Plate 3, Figures 1 and 3). It is covered with variable thicknesses of undifferentiated Quaternary sediments in the current study area (Scott et al., in preparation).

The Williston Karst Plain merges with the Branford Karst Plain and Chiefland Karst Plain north of the study area (OFMS 101; Plate 3, Figure 3). Within the mapped area, elevations of the province range from $49 \mathrm{ft}(14.9 \mathrm{~m})$ to $102 \mathrm{ft}(31.1 \mathrm{~m})$ above MSL. Much of the plain is well drained and a number of springs, including the Rainbow Springs Group, just east of the current study area, occur within this province.

\section{LITHOSTRATIGRAPHIC UNITS}

\section{Tertiary System}

\section{Eocene Series}

\section{Avon Park Formation}

The Middle Eocene Avon Park Formation (Tap), first described by Applin and Applin (1944), is the oldest unit investigated in the present study area. The unit consists of cream to light-brown to tan, poorly- to well indurated, variably fossiliferous limestone (grainstone to wackestone, with rare mudstone). The limestones are interbedded with tan to brown, very poorly- to well indurated, very fine to medium crystalline, fossiliferous (molds and casts), vuggy dolostones, and organics are often present. Fossils present in the unit include mollusks, foraminifera (Spirolina sp., Lituonella floridana, Bolivina sp., and Dictyoconus americanus), echinoids, algae and carbonized plant remains.

The Avon Park Formation both underlies the mapped area and is exposed in the central to south-central regions of the study area. The top of the Avon Park ranges from $98 \mathrm{ft}(29.9 \mathrm{~m})$ below MSL in W-12615 (OFMS 101; Plate 2, cross-sections A-A' and E-E') to $26 \mathrm{ft}$ (7.9 m) above MSL at the top of W-9434. No wells utilized for cross-sections penetrated the entire thickness of the Avon Park Formation. In locations mapped as Avon Park Formation at the surface, it is possible to find outlier remnants of Upper Eocene Ocala Limestone (To) or shelly Pleistocene sediments (Qu). The Avon Park Formation forms part of the Floridan aquifer system (Southeastern Geological Society Ad Hoc Committee on Florida Hydrostratigraphic Unit Definition, 1986).

\section{Ocala Limestone}

The Upper Eocene Ocala Limestone (To), first described by Dall and Harris (1892), is a biogenic marine limestone comprised largely of foraminifera, mollusks, echinoids and bryozoans. Where present, the Ocala Limestone sits unconformably on the Avon Park 
Formation. When the Ocala Limestone is absent, the Avon Park Formation may be in direct, unconformable contact with the overlying undifferentiated Quaternary sediments $(\mathrm{Qu})$. The Ocala Limestone is recrystallized to varying degrees within the study area, making the contact between the two units difficult to discern. Based on lithologic differences, the Ocala Limestone can be informally subdivided into an upper and lower unit (Scott, 1991b). This subdivision, while often apparent in cores and quarries, is not readily apparent in cuttings. As a consequence of this, the geologic cross-sections do not break out the upper and lower Ocala Limestone.

The upper unit is typically a white to cream, fine- to coarse grained, poorly- to well indurated, moderately- to well sorted, very fossiliferous limestone (wackestone, packstone, and grainstone). Fossils commonly include foraminifera (Lepidocyclina ocalana), bryozoans, mollusks, and a rich diversity of echinoids. The lower unit is typically a white to cream, fine- to medium grained, poorly- to moderately indurated, moderately- to well sorted limestone (grainstone to packstone). Fossils include foraminifera (Amphistegina pinarensis cosdensi, Nummulites [Camerina] vanderstoki, Nummulites [Operculinoides] ocalana), bryozoans, algae, mollusks, echinoids, and crabs.

The top of the Ocala Limestone ranges from $56.2 \mathrm{ft}(17.1 \mathrm{~m})$ above MSL in W-19071 (OFMS 101; Plate 2, cross-sections A-A' and $\mathrm{H}^{-\mathrm{H}^{\prime}}$ ) to $7 \mathrm{ft}(2.1 \mathrm{~m})$ below MSL in W-14689 (OFMS 101; Plate 2, cross-section C-C'). Most of the wells utilized for geologic cross sections penetrate the entire thickness of the Ocala Limestone. In these wells, the thickness of the Ocala Limestone ranges from less than $10 \mathrm{ft}(3.1 \mathrm{~m})$ in several wells on several cross-sections (OFMS 101; Plate 2) to $115 \mathrm{ft}(35.1 \mathrm{~m})$ in $\mathrm{W}-17583$ (OFMS 101; Plate 2, cross-sections A-A' and F-F'). In areas near outcrops of the Avon Park Formation, the Ocala Limestone thins, and it is possible to find outlier rock outcrops of Avon Park Formation. The Ocala Limestone is generally thickest in the northwestern portion of the study area off the nose of the Ocala Platform. The Ocala Limestone forms part of the Floridan aquifer system (Southeastern Geological Society Ad Hoc Committee on Florida Hydrostratigraphic Unit Definition, 1986).

\section{Miocene Series}

\section{Hawthorn Group}

Sediments of the Miocene Hawthorn Group are thought to have been deposited over the Ocala Platform throughout the area, but post-Miocene erosion and karstification has removed sediments from the crest of the Ocala Platform, exposing the Eocene carbonates in the central and southern portion of the map area (Cooke, 1945; Espenshade and Spencer, 1963; Scott, 1981b). Fossils in the Hawthorn Group are sparse but may include vertebrate remains, corals, and mollusks. Williams et al. (1977) report that the most commonly found fossils are oysters and coral heads. Within the mapped area, the Hawthorn Group is composed of undifferentiated Hawthorn Group (Th) sediments, and was only observed in the subsurface in cores and cuttings.

\section{Undifferentiated Hawthorn Group}

Undifferentiated Hawthorn Group (Th) sediments are light olive gray and blue gray in unweathered sections and reddish brown in weathered sections. They consist of poorly to moderately consolidated, clayey sands to silty clays and relatively pure clays with little to no phosphate due to leaching and transport (Scott, 2001). These sediments are present in the subsurface of the northern Brooksville Ridge, and in the subsurface of the southeast portion of 
the map area (OFMS 101; Plate 1). They are often deeply weathered. In the Brooksville Ridge, undifferentiated Hawthorn Group sediments are often overlain by more than $20 \mathrm{ft}(6.1 \mathrm{~m})$ of undifferentiated Tertiary and Quaternary sediments (TQu) and/or Quaternary sediments (Qu). Hard-rock phosphate deposits are associated with the undifferentiated Hawthorn Group sediments in several places along the eastern flank of the Brooksville Ridge. These hard-rock phosphate deposits were formed by dissolution of phosphates from the Hawthorn Group and subsequent precipitation in karst features within the Ocala Limestone (Scott, 2001).

Where present, Hawthorn Group sediments unconformably overlie the Ocala Limestone (Scott, 1988). They are unconformably overlain by undifferentiated Quaternary sediments $(\mathrm{Qu})$. Very thin beds of the undifferentiated Hawthorn Group were only penetrated in a few wells in the eastern portion of the map area. In these, the top of the Hawthorn Group ranges from $37 \mathrm{ft}$ (11.3 m) above MSL in W-15682 (OFMS 101; Plate 2, cross-sections B-B' and $\mathrm{H}-\mathrm{H}^{\prime}$ ) to $32 \mathrm{ft}$ $(9.8 \mathrm{~m})$ above MSL in W-19226 (OFMS 101; Plate 2, cross-sections C-C' and $\left.\mathrm{H}-\mathrm{H}^{\prime}\right)$. The undifferentiated Hawthorn Group is only 10-20 ft (3.1-6.1 m) thick in each of these cores. These are maximum thicknesses for this unit and are not necessarily laterally continuous. Sediments are often clayey sands with some permeability, and only rarely consist of relatively pure clays. The undifferentiated Hawthorn Group sediments generally have low permeability and form part of the intermediate aquifer system/intermediate confining unit (Southeastern Geological Society Ad Hoc Committee on Florida Hydrostratigraphic Unit Definition, 1986).

\section{Tertiary/Quaternary Systems}

\section{Pliocene Series}

\section{Undifferentiated Tertiary/Quaternary Sediments}

Undifferentiated Tertiary/Quaternary sediments (TQu) are siliciclastics that are separated from the lithologically similar undifferentiated Quaternary sediments solely on the basis of elevation (Scott et al., 2001). Pleistocene sea levels reached a maximum of approximately $100 \mathrm{ft}$ (30.5 m) above MSL (Colquhoun, 1969). The sediments which occur above $100 \mathrm{ft}(30.5 \mathrm{~m})$ MSL are predominately older than Pleistocene but may have been reworked during the Pleistocene. They are present along the southeastern edge of the map area in the Brooksville Ridge (OFMS 101; Plate 1) in areas where elevations exceed $100 \mathrm{ft}(30.5 \mathrm{~m})$. Some areas below $100 \mathrm{ft}(30.5 \mathrm{~m})$ may be included in the undifferentiated Tertiary/Quaternary sediments where not including them would have created very complex map polygons. These poorly consolidated to unconsolidated siliciclastics are white to gray to orange to blue-green, fine to coarse grained, clean to clayey unfossiliferous sands, sandy clays and clays with variable admixtures of clay and organics. Permeable sediments of the undifferentiated Tertiary/Quaternary sediments form part of the surficial aquifer system (Southeastern Geological Society Ad Hoc Committee on Florida Hydrostratigraphic Unit Definition, 1986).

\section{Pleistocene Series}

\section{Undifferentiated Quaternary Sediments}

Undifferentiated Quaternary sediments $(\mathrm{Qu})$ lie unconformably on either the Avon Park Formation, the Ocala Limestone or on undifferentiated Hawthorn Group sediments. The Avon 
Park Formation and the undifferentiated Quaternary sediments are only in direct contact where the Ocala Limestone has been completely removed from the section.

The undifferentiated Quaternary sediments present in the eastern portions of the mapped area are highly variable in thickness. Data from this project indicate that the surface of the Ocala Limestone in these areas is heavily karstified. Overlying sediments may range from $20 \mathrm{ft}(6.1 \mathrm{~m})$ to over $70 \mathrm{ft}(21.3 \mathrm{~m})$ thick in the Brooksville Ridge. Relief on the surface of the Ocala Limestone can easily exceed $30 \mathrm{ft}(9.1 \mathrm{~m})$ in karstic areas. Much of these undifferentiated sediments are derived from erosion and weathering of Hawthorn Group and younger units, and sinkholes may contain Hawthorn Group sediments (Scott, 1992). Field evidence also shows that pinnacles of Ocala Limestone and outliers of weathered Hawthorn Group sediments can occur in these areas. The western edge of the extent of mappable undifferentiated Quaternary sediments occurs in association with several relict shoreline ridges which are located to the west of the Brooksville Ridge and are previously discussed in the geomorphology section of this report.

Generally, these undifferentiated Quaternary sediments consist of white to gray to orange to blue-green, fine to coarse grained, clean to clayey unfossiliferous sands, sandy clays and clays with variable admixtures of organics. They are only separated from the undifferentiated Tertiary/Quaternary sediments due to current elevations below $100 \mathrm{ft}(30.5 \mathrm{~m})$. The undifferentiated Quaternary sediments form part of the surficial aquifer system (Southeastern Geological Society Ad Hoc Committee on Florida Hydrostratigraphic Unit Definition, 1986). Where these sediments lack clays and overlie the Eocene limestones, they are hydraulically connected to the Floridan aquifer system.

\section{Shelly Pleistocene Sediments}

Several thin and discontinuous deposits of shelly Pleistocene sediments $(\mathrm{Qu})$ were encountered within the study area. Aerial extent of the unit did not meet criteria to be mappable. The majority of these were in the Lebanon Station and northern Yankeetown USGS 7.5 minute quadrangles. The samples consist of medium quartz sand with pelecypod shells cemented to form well-indurated, fossiliferous sandstone. The samples were often found in conjunction with the Upper Eocene Ocala Limestone and/or the Middle Eocene Avon Park Formation. At one locality, there were Ocala Limestone rip-up clasts in the sample (OFMS 101; Plate 3, Photo 5). These may correlate to the sediments referred to as the Pamlico Formation in Vernon (1951). Personal communication with Roger Portell with the Florida Museum of Natural History in Gainesville, Florida confirms that samples, other than those collected for the present study, of deposits of this nature have been found in the Waccasassa River basin. Based upon his and his students' studies of the biostratigraphy, these sediments are age equivalent to the Pleistocene Caloosahatchee Formation. This is the northernmost extent of these sediments found to date in Florida.

\section{Quaternary Beach Ridge and Dune}

The sediments of the Beach Ridge and Dune are a subdivision of the undifferentiated Quaternary sediments that are noted on the basis of surficial expression of beach ridges and dunes. These sediments typically unconformably overlie the Ocala Limestone, but may exist in contact with the Avon Park Formation where the Ocala Limestone has been removed from the section. Beach Ridge and Dune sediments occur in the southeastern part of the study area south 
of the Withlacoochee River in Citrus County on the western flank of the southern Brooksville Ridge. They are also present in eastern Levy County, as previously discussed, and along the western boundary of the study area in isolated regions between Cedar Key and Manatee Spring. However, both of these deposits are thin and/or do not cover a significant enough area to be mappable on OFMS 101; Plate 1. Subdivisions of the undifferentiated Quaternary Sediments are not formally recognized lithostratigraphic units, but are noted to facilitate a better understanding of Florida's Quaternary geology (Scott, 2001).

Beach Ridge and Dune sediments are dominantly siliciclastic sands and are unconsolidated to poorly consolidated. Organics typically occur as disseminated organic matrix, roots and plant debris, carbonized remains or charcoal. These sediments are considered part of the surficial aquifer system (Southeastern Geological Society Ad Hoc Committee on Florida Hydrostratigraphic Unit Definition, 1986).

\section{HYDROGEOLOGY}

The hydrogeology of the map area consists of (in ascending order) the Floridan aquifer system (FAS), the intermediate aquifer system/intermediate confining unit (IAS/ICU), and the surficial aquifer system (SAS) (Southeastern Geological Society Ad Hoc Committee on Florida Hydrostratigraphic Unit Definition, 1986). The FAS, the primary source for springs and drinking water in the region, is generally comprised of carbonate units of the Avon Park Formation and the Ocala Limestone. The sands, silts, clays and carbonates of the Hawthorn Group comprise the IAS/ICU. The IAS/ICU is highly localized and laterally discontinuous in the study area. The SAS is comprised of the undifferentiated Tertiary/Quaternary sediments (TQu), the undifferentiated Quaternary sediments $(\mathrm{Qu})$ and the Beach Ridge and Dune sediments (Qbd).

Where siliciclastic sediments of the Hawthorn Group and younger units are thick and continuous, they provide confinement for the FAS, but where the siliciclastic sediments of the Hawthorn Group and younger units are thin, missing or lack significant clay component, karst features often occur. Swallets (stream-to-sink features) are of particular concern to geoscientists and hydrogeologists. The only one documented in the study area is on Horse Hole Creek, north of Inglis. Overland flow is captured by the swallet thus allowing for direct recharge to the FAS by surface water which potentially consists of runoff from agricultural and urban areas (OFMS 101; Plate 3, Figure 1 and Photo 2).

\section{DERIVATIVE PRODUCTS}

Several derivative products will come from this project. During the mapping project, data from over 200 wells were analyzed (Appendix A includes those within the study area boundary, other than several in the Manatee Springs quadrangle that were not included due to map labeling density, and top of limestone rock information from Water Management District wells). Formation picks, made on all available wells with cores and cuttings samples, will allow for the creation of a structure contour map of the top of the Floridan aquifer system, along with the creation of structure contour and isopach maps of the intermediate confining unit in the area. Additional derivative data anticipated to come from this mapping effort include aquifer vulnerability assessment maps. Data derived from prior STATEMAP products have often been used to augment other Florida Geological Survey and Florida Aquifer Vulnerability Assessment (FAVA) projects in the State (Arthur et al., 2007; Baker et al., 2007). 


\section{FLORIDA GEOLOGICAL SURVEY}

\section{REFERENCES}

Adams, P.N., Opdyke, N.D. and Jaeger, J.M., 2010, Isostatic uplift driven by karstification and sea-level oscillation: Modeling landscape evolution in North Florida: Geology, v. 38, no. 6, p. 531-534.

Allison, D., Groszos, M., and Rupert, F., 1995, Top of rock of the Floridan aquifer system in the Suwannee River Water Management District: Florida Geological Survey Open-File Map Series 84, scale 1:475,000.

Alt, D. and Brooks, H.K., 1965, Age of the Florida marine terraces: Journal of Geology, v. 73, no. 2, p. 406-411.

Applin, P., 1951, Possible future petroleum provinces of North America - Florida: American Association of Petroleum Geologists Bulletin, v. 35, p. 405-407.

Applin, P.L. and Applin, E.R., 1944, Regional subsurface stratigraphy and structure of Florida and southern Georgia: American Association of Petroleum Geologists Bulletin, v. 28, p. 1673-1753.

Arthur, J.D., Wood, H.A.R., Baker, A.E., Cichon, J.R. and Raines, G.L., 2007, Development and implementation of a Bayesian-based aquifer vulnerability assessment in Florida: Natural Resources Research, v. 16, no. 2, p. 93-107.

Baker, A.E., Wood, H.A.R. and Cichon, J.R., 2007, The Marion County Aquifer Vulnerability Assessment: unpublished report submitted to Marion County Board of County Commissioners in fulfillment of Marion County Project No. SS06-01, March 2007, 42 p.

Bryan, J.R., 2004, Larger foraminifera: Introduction, biology, ecology, taxonomic and stratigraphic listings and comments on Florida fossil assemblages: Florida Paleontological Society, Florida Fossil Invertebrates, Part 6, 28 p.

Campbell, K.M., 1992a, Geologic map of Dixie County, Florida: Florida Geological Survey Open-File Map Series 35, Scale 1:126,720.

Campbell, K.M., 1992b, Geologic map of Levy County, Florida: Florida Geological Survey Open-File Map Series 11, Scale 1:126,720.

Campbell, K.M., and Scott, T.M., 1992, Geologic Map of Citrus County, Florida: Florida Geological Survey Open-File Map Series 10, Scale 1:126,720.

Col, N., Rupert, F., Enright, M. and Horvath, G., 1997, Reappraisal of the geology and hydrogeology of Gilchrist County, Florida, with emphasis on the Waccasassa Flats: Florida Geological Survey Report of Investigation 99, 76 p. 


\section{OPEN-FILE REPORT 94}

Colquhoun, D.J., 1969, Coastal plain terraces in the Carolinas and Georgia, U.S.A., in Wright, H.E., Jr., ed., Quaternary Geology and Climate: Volume 16 of the Proceedings of the VII Congress of the International Association for Quaternary Research, p. 150-162.

Cooke, C.W., 1931, Seven coastal terraces in the southeastern United States: Washington Academy of Sciences Journal, v. 21, p. 503-513.

Cooke, C.W., 1939, Scenery of Florida interpreted by a geologist: Florida Geological Survey Bulletin 17, $120 \mathrm{p}$.

Cooke, C.W., 1945, Geology of Florida: Florida Geological Survey Bulletin 29, 342 p.

Copeland, R., 2003, Florida spring classification system and spring glossary: Florida Geological Survey Special Publication 52, 17 p.

Dall, W.H. and Harris, G.D., 1892, Correlation papers, Neocene: United States Geological Survey Bulletin 84, 349 p.

Espenshade, G.H. and Spencer, C.W., 1963, Geologic features of phosphate deposits of northern peninsular Florida: United States Geological Survey Bulletin 1118, 115 p.

Evans, W.L., III, Green, R.C., Bryan, J.R. and Paul, D.T., 2004, Geologic map of the western portion of the USGS 1:100,000 scale Gainesville quadrangle, northern Florida: Florida Geological Survey Open-File Map Series 93, 2 plates, scale 1:100,000.

Flint, R.F., 1940, Pleistocene features of the Atlantic coastal plain: American Journal of Science, v. 238 , p. $757-787$.

Flint, R.F., 1971, Glacial and Quaternary Geology: New York, John Wiley and Sons, Inc., 892 p.

Green, R.C., Evans, W.L., III, Paul, D.T., and Scott, T.M., 2005, Geologic map of the eastern portion of the USGS 1:100,000 scale Gainesville quadrangle, northern Florida: Florida Geological Survey Open-File Map Series 94, scale 1:100,000, 2 plates.

Green, R.C., Williams, C.P., Paul, D.T., Kromhout, C. and Scott, T.M., 2009a, Geologic map of the eastern portion of the USGS Ocala 30 x 60 minute quadrangle, north-central Florida: Florida Geological Survey Open-File Map Series 100, scale 1:100,000, 3 plates.

Green, R.C., Williams, C.P., Paul, D.T., Kromhout, C. and Scott, T.M., 2009b, Text to accompany geologic map of the eastern portion of the USGS Ocala 30 x 60 minute quadrangle, north-central Florida: Florida Geological Survey Open-File Report 93, 29 p.

Groszos, M. and Rupert, F.R., 1992, An isopach map of the Hawthorn Group in the Suwannee River Water Management District: Florida Geological Survey Open-File Map Series 2, scale 1:250, 000. 


\section{FLORIDA GEOLOGICAL SURVEY}

Healy, H.G., 1975, Terraces and shorelines of Florida: Florida Geological Survey Map Series 71, scale: 1:2,095,200.

Hopkins, O.B., 1920, Drilling for oil in Florida: United States Geological Survey Press Bulletin, April, 1920.

Jones, G.W., Upchurch, S.B., and Champion, K.M., 1996, Origin of nitrate in groundwater discharging from Rainbow Springs, Marion County, Florida: Southwest Florida Water Management District Report, 155 p.

MacNeil, F.S., 1950, Pleistocene shorelines in Florida and Georgia: U.S. Geological Survey Professional Paper 221-F, p. 95-107.

Matson, G.C. and Sanford, S., 1913, Geology and groundwater of Florida: U.S. Geological Survey Water Supply Paper 319, 445 p.

Miller, J.A., 1986, Hydrogeologic framework of the Florida aquifer system in Florida and in parts of Georgia, Alabama, and South Carolina: Regional Aquifer-System Analysis: U.S. Geological Survey Professional Paper 1403-B, 91 p., 33 plates.

Phelps, G.G., 1994, Hydrogeology, water quality and potential for contamination of the Upper Floridan Aquifer in the Silver Springs Ground-Water Basin, Central Marion County, Florida: U.S. Geological Survey Water-Resources Investigations Report 92-4159, 69 p.

Phelps, G.G., 2004, Chemistry of groundwater in the Silver Springs Basin, with an emphasis on Nitrate: U.S. Geological Survey Scientific Investigations Report 2004-5144, 54 p.

Pirkle, E.C., Jr., Yoho, W.H. and Hendry, C.W., Jr., 1970, Ancient sea level stands in Florida: Florida Geological Survey Bulletin 52, 61 p.

Puri, H.S., 1957, Stratigraphy and zonation of the Ocala Group: Florida Geological Survey Bulletin 38, 248 p.

Puri, H.S. and Vernon, R.O., 1964, Summary of the geology of Florida and a guidebook to the classic exposures: Florida Geological Survey Special Publication 5, revised, 312 p.

Puri, H.S., Yon, J.W., Jr. and Oglesby, W.R., 1967, Geology of Dixie and Gilchrist Counties, Florida: Florida Geological Survey Bulletin 49, 155 p.

Schmidt, W., 1984, Neogene stratigraphy and geologic history of the Apalachicola Embayment: Florida Geological Survey Bulletin 58, 146 p.

Scott, T.M., 1981a, The paleo-extent of the Miocene Hawthorn Formation in peninsular Florida [abstract]: Florida Scientist, v. 44, Supplement 1, p. 42. 
Scott, T.M., 1981b, The Hawthorn Formation of North Florida: Southeastern Geological Society, Field Conference Guidebook, v. 23, p. 15-23.

Scott, T.M., 1988, The lithostratigraphy of the Hawthorn Group (Miocene) of Florida: Florida Geological Survey Bulletin 59, 148 p.

Scott, T.M., 1991a, Depositional patterns of the Hawthorn Group in Florida: Geological Society of America Abstracts with Programs, v. 23, p. 126.

Scott, T.M., 1991b, A geological overview, in Scott, T.M., Lloyd, J.M. and Maddox, G.L., eds., 1991, Florida's ground-water quality monitoring program, hydrogeologic framework: Florida Geological Survey Special Publication 32, 97 p.

Scott, T.M., 1992, Geologic map of Marion County, Florida: Florida Geological Survey OpenFile Map Series 13, scale 1:126,720.

Scott, T.M., 1997, Miocene to Holocene history of Florida, in Randazzo, A.F. and Jones, D.S., eds., 1997, The geology of Florida: Gainesville, University Press of Florida, 327 p.

Scott, T.M., 2001, Text to accompany the geologic map of Florida: Florida Geological Survey Open-File Report 80, 29 p.

Scott, T.M., 2005, Revisions to the geomorphology of Florida focusing on the eastern panhandle and north-central Florida, in Southeastern Geological Society Field Trip Guidebook 44, p. 18-36.

Scott, T.M., and Campbell, K.M., 1992, Geologic map of Alachua County, Florida: Florida Geological Survey Open-File Map Series 12, scale 1:126,720.

Scott, T.M., Paul, D.T., Means, G.H. and Williams, C.P. (in preparation) Geomorphic map of Florida: Florida Geological Survey, scale 1:750,000.

Scott, T.M., Campbell, K.M., Rupert, F.R., Arthur, J.A., Green, R.C., Means, G.H., Missimer, T.M., Lloyd, J.M. and Duncan, J.G., 2001, Geologic map of Florida: Florida Geological Survey Map Series 146, scale 1:750,000.

Scott, T.M., Means, G.H., Means, R.C. and Meegan R.P., 2002, First magnitude springs of Florida: Florida Geological Survey Open-File Report 85, 138 p.

Scott, T.M., Means, G.H., Meegan, R.P., Means, R.C., Upchurch, S.B., Copeland, R.E., Jones, J., Roberts, T. and Willet, A., 2004, Springs of Florida: Florida Geological Survey Bulletin 66, $377 \mathrm{p}$.

Sinclair, W.C., and Stewart, J.W., 1985, Sinkhole type, development, and distribution in Florida: Florida Geological Survey Map Series 110, scale 30 miles to 1 inch. 


\section{FLORIDA GEOLOGICAL SURVEY}

Southeastern Geological Society Ad Hoc Committee on Florida Hydrostratigraphic Unit Definition, 1986, Hydrogeological units of Florida: Florida Geological Survey Special Publication 28, 8 p.

Upchurch, S.B., Champion, K.M., Schnieder, J.C., Hornsby, D., Ceryak, R. and Zwanka, W., 2004, Defining springshed boundaries and water-quality domains near first-magnitude springs in north Florida [abstract]: Florida Scientist, v. 67, Supplement 1, 52 p.

U.S. Geological Survey, 1978, 1:100,000-scale metric topographic map of Ocala, Florida: Reston, U.S. Geological Survey, 1 sheet.

Vernon, R.O., 1951, Geology of Citrus and Levy Counties, Florida: Florida Geological Survey Bulletin 33, $256 \mathrm{p}$.

White, W.A., 1970, The geomorphology of the Florida peninsula: Florida Geological Survey Bulletin 51, $164 \mathrm{p}$.

Williams, K.E., Nicol, D. and Randazzo, A.F., 1977, The geology of the western part of Alachua County, Florida: Florida Geological Survey Report of Investigation 85, 97 p.

Yon, J.W., Jr. and Puri, H.S., 1962, Geology of Waccasassa Flats, Gilchrist County, Florida: American Association of Petroleum Geologists Bulletin, v. 46, no. 5, p. 674-684. 


\section{OPEN-FILE REPORT 94}

\section{ACKNOWLEDGEMENTS}

The authors extend many thanks to the personnel that assisted with access to land holdings: Mickey Thomason and Chris McKendree with the Marjorie Harris Carr Cross-Florida Greenway, Office of Greenways and Trails, Florida Department of Environmental Protection, Sherry Bennett and staff at Goethe State Forest who provided much assistance with road access and facilitating coring on their lands, Matt Weldon with Levy County for coring at Blue Spring County Park and in Devil's Hammock, E.T. Usher and Lynetta Griner who were gracious to allow us access to place a core on an Usher Land and Timber, Inc. land holding in Levy County, and to Chris Turner and Kendall Fountain with the Plum Creek Timber Company, Inc. who worked out a way for us to complete escorted reconnaissance of some of their land holdings.

Kristin Ebersol and Tommy Allen with the Waccasassa Bay Preserve State Park and Cedar Key Scrub State Reserve provided invaluable assistance worthy of special note. They assisted with names of local contacts, information about possible rock outcrops and old pits in areas of the Parks and along roadways leading to the Parks. Anytime we needed a local opinion, Kristin and Tommy were there. This work would not have been as successful were it not for your support and contributions. Thank you!

Ken Campbell, David Paul, Jesse Hurd, Guy Richardson and Eric Thomas provided field support for drilling operations. Amber Raynsford and Lisa Fulton worked to make sure all wells were appropriately located using every piece of archived well location information that could be found. Alexandra Walrath compiled the data layers and produced the base map and completed labeling of all significant features. Drew Butler assisted with location of elusive cores and cuttings samples as well as description of many of the M-series for this project. Eric Thomas, Jake Mast, James Bobrycki and John Carroll also assisted on several occasions with work to locate and move core and cuttings samples from the FGS Sample Respository to the STATEMAP Laboratory. Guy Harley Means provided boat captain assistance for field work along the Levy County coast tidal creeks and rivers as well as the lower portion of the Withlacoochee River. Thank you to Frank Rupert, Jackie Lloyd and Harley Means who reviewed, discussed and edited the product. The geologic map was funded in part by the Office of the Florida Geological Survey of the Florida Department of Environmental Protection and by the United States Geological Survey National Cooperative Geologic Mapping Program under USGS assistance award number 09HQPA0003. 
FLORIDA GEOLOGICAL SURVEY

\section{APPENDIX A: WELLS UTILIZED FOR STUDY}

\begin{tabular}{|c|c|c|c|c|c|c|c|c|}
\hline Map ID & Well Label & Data Source & Sample Type & Longitude & Latitude & 24K Quad & $\begin{array}{c}\text { Elevation } \\
(\mathrm{ft})\end{array}$ & $\begin{array}{c}\text { Total Depth } \\
\text { (ft) }\end{array}$ \\
\hline 1 & W-211 & FGS & CUTTINGS & -82.647390 & 29.304200 & BRONSON SW & 40 & 70 \\
\hline 2 & W-212 & FGS & CUTTINGS & -82.725890 & 29.253250 & BRONSON SW & 12 & 40 \\
\hline 3 & W-331 & FGS & CUTTINGS & -82.750170 & 29.208090 & WACCASASSA BAY & 7 & 50 \\
\hline 4 & W-871 & FGS & CUTTINGS & -82.706920 & 29.347280 & BRONSON SW & 35 & 679 \\
\hline 5 & W-1202 & FGS & CUTTINGS & -82.561290 & 29.044750 & YANKEETOWN SE & 30 & 70 \\
\hline 6 & W-1241 & FGS & CUTTINGS & -82.784330 & 29.180310 & WACCASASSA BAY & 5 & 16 \\
\hline 7 & W-1844 & FGS & CUTTINGS & -82.860690 & 29.417250 & CHIEFLAND & 33 & 440 \\
\hline 8 & W-1848 & FGS & CUTTINGS & -82.563510 & 29.007800 & YANKEETOWN SE & 42 & 1105 \\
\hline 9 & W-1849 & FGS & CUTTINGS & -82.816950 & 29.299110 & OTTER CREEK & 21 & 670 \\
\hline 10 & W-7111 & FGS & CORE & -82.814610 & 29.215310 & WACCASASSA BAY & 5 & 70 \\
\hline 11 & W-7114 & FGS & CORE & -82.795160 & 29.214480 & WACCASASSA BAY & 5 & 61 \\
\hline 12 & W-7116 & FGS & CORE & -82.803220 & 29.228370 & WACCASASSA BAY & 5 & 55 \\
\hline 13 & W-7421 & FGS & CUTTINGS & -82.920820 & 29.304480 & CHIEFLAND SW & 25 & 75 \\
\hline 14 & W-7619 & FGS & CORE & -82.852380 & 29.216980 & WACCASASSA BAY & 5 & 55 \\
\hline 15 & W-7896 & FGS & CUTTINGS & -82.647950 & 29.066690 & YANKEETOWN & 40 & 37 \\
\hline 16 & W-7898 & FGS & CUTTINGS & -82.619760 & 29.020020 & YANKEETOWN SE & 30 & 225 \\
\hline 17 & W-9436 & FGS & CUTTINGS & -82.577400 & 29.104190 & YANKEETOWN SE & 52 & 570 \\
\hline 18 & W-9437 & FGS & CUTTINGS & -82.644340 & 29.028910 & YANKEETOWN & 26 & 495 \\
\hline 19 & W-9438 & FGS & CUTTINGS & -82.690560 & 29.220580 & LEBANON STATION & 17 & 455 \\
\hline 20 & W-9439 & FGS & CUTTINGS & -82.627390 & 29.103640 & YANKEETOWN & 40 & 465 \\
\hline 21 & W-9441 & FGS & CUTTINGS & -82.644340 & 29.163360 & LEBANON STATION & 24 & 547 \\
\hline 22 & W-9446 & FGS & CUTTINGS & -82.732110 & 29.280310 & BRONSON SW & 16 & 400 \\
\hline 23 & W-9447 & FGS & CUTTINGS & -82.863770 & 29.336150 & OTTER CREEK & 30 & 440 \\
\hline 24 & W-12582 & FGS & CORE & -82.674430 & 29.026980 & YANKEETOWN & 13 & 88 \\
\hline 25 & W-12615 & FGS & CORE & -82.975150 & 29.479490 & MANATEE SPRINGS & 14 & 496 \\
\hline 26 & W-12726 & FGS & CUTTINGS & -82.593510 & 29.013910 & YANKEETOWN SE & 30 & 72 \\
\hline 27 & W-14519 & FGS & CORE & -82.728230 & 29.027800 & YANKEETOWN & 9 & 255 \\
\hline 28 & W-14689 & FGS & CUTTINGS & -82.996540 & 29.232810 & SUMNER & 8 & 46 \\
\hline 29 & W-15682 & FGS & CORE & -82.557670 & 29.333360 & BRONSON SE & 72 & 354 \\
\hline 30 & W-17583 & FGS & CUTTINGS & -82.848210 & 29.463090 & CHIEFLAND & 35 & 320 \\
\hline 31 & W-19067 & FGS & CORE & -82.698350 & 29.451680 & BRONSON & 44 & 116 \\
\hline 32 & W-19069 & FGS & CORE & -82.936220 & 29.237830 & SUMNER & 16 & 100 \\
\hline 33 & W-19071 & FGS & CORE & -82.544167 & 29.445300 & BRONSON NE & 90 & 130 \\
\hline 34 & W-19206 & FGS & CORE & -82.976389 & 29.392778 & MANATEE SPRINGS & 12 & 110.75 \\
\hline 35 & W-19215 & FGS & CORE & -82.733055 & 29.396112 & BRONSON & 32 & 121 \\
\hline 36 & W-19226 & FGS & CORE & -82.575647 & 29.271732 & BRONSON SE & 78 & 0 \\
\hline 37 & W-172 & FGS & CUTTINGS & -82.528610 & 29.368600 & BRONSON SE & 90 & 124 \\
\hline 38 & W-209 & FGS & CUTTINGS & -82.619620 & 29.006690 & YANKEETOWN SE & 26 & 70 \\
\hline 39 & W-210 & FGS & CUTTINGS & -82.717120 & 29.029470 & YANKEETOWN & 12 & 54 \\
\hline 40 & W-214 & FGS & CUTTINGS & -82.600180 & 29.332160 & BRONSON SE & 72 & 95 \\
\hline 41 & $W-330$ & FGS & CUTTINGS & -82.728060 & 29.230900 & LEBANON STATION & 10 & 50 \\
\hline 42 & W-333 & FGS & CUTTINGS & -82.717390 & 29.241420 & LEBANON STATION & 12 & 40 \\
\hline 43 & W-379 & FGS & CUTTINGS & -82.734610 & 29.243920 & LEBANON STATION & 10 & 50 \\
\hline 44 & W-380 & FGS & CUTTINGS & -82.738500 & 29.275870 & BRONSON SW & 17 & 40 \\
\hline 45 & W-501 & FGS & CUTTINGS & -82.728180 & 29.248500 & LEBANON STATION & 9 & 373 \\
\hline 46 & W-664 & FGS & CUTTINGS & -82.825510 & 29.296700 & OTTER CREEK & 20 & 20 \\
\hline 47 & W-866 & FGS & CUTTINGS & -82.773110 & 29.320550 & OTTER CREEK & 28 & 102 \\
\hline 48 & W-1112 & FGS & CUTTINGS & -82.534900 & 29.031410 & YANKEETOWN SE & 72 & 56 \\
\hline 49 & W-1201 & FGS & CUTTINGS & -82.561290 & 29.044750 & YANKEETOWN SE & 30 & 70 \\
\hline 50 & W-1203 & FGS & CUTTINGS & -82.594750 & 29.036080 & YANKEETOWN SE & 31 & 72 \\
\hline 51 & W-1204 & FGS & CUTTINGS & -82.609710 & 29.029720 & YANKEETOWN SE & 29 & 69 \\
\hline 52 & W-1205 & FGS & CUTTINGS & -82.609710 & 29.029720 & YANKEETOWN SE & 28 & 24 \\
\hline 53 & W-1206 & FGS & CUTTINGS & -82.609710 & 29.029720 & YANKEETOWN SE & 31 & 33 \\
\hline 54 & W-1207 & FGS & CUTTINGS & -82.609710 & 29.029720 & YANKEETOWN SE & 31 & 81 \\
\hline 55 & W-1209 & FGS & CUTTINGS & -82.609710 & 29.029720 & YANKEETOWN SE & 29 & 24 \\
\hline 56 & W-1210 & FGS & CUTTINGS & -82.609710 & 29.029720 & YANKEETOWN SE & 30 & 32 \\
\hline 57 & W-1211 & FGS & CUTTINGS & -82.616840 & 29.022800 & YANKEETOWN SE & 31 & 101 \\
\hline 58 & W-1212 & FGS & CUTTINGS & -82.625130 & 29.027690 & YANKEETOWN & 29 & 69 \\
\hline
\end{tabular}


OPEN-FILE REPORT 94

\begin{tabular}{|c|c|c|c|c|c|c|c|c|}
\hline Map ID & Well Label & Data Source & Sample Type & Longitude & Latitude & 24K Quad & $\begin{array}{c}\text { Elevation } \\
(\mathrm{ft})\end{array}$ & $\begin{array}{c}\text { Total Depth } \\
\text { (ft) }\end{array}$ \\
\hline 59 & W-1213 & FGS & CUTTINGS & -82.644620 & 29.011970 & YANKEETOWN & 10 & 50 \\
\hline 60 & W-1214 & FGS & CUTTINGS & -82.657400 & 29.011410 & YANKEETOWN & 19 & 59 \\
\hline 61 & W-1215 & FGS & CUTTINGS & -82.657670 & 29.011140 & YANKEETOWN & 18 & 59 \\
\hline 62 & W-1217 & FGS & CUTTINGS & -82.675450 & 29.012250 & YANKEETOWN & 14 & 54 \\
\hline 63 & W-1218 & FGS & CUTTINGS & -82.691246 & 29.006750 & YANKEETOWN & 11 & 51 \\
\hline 64 & W-1219 & FGS & CUTTINGS & -82.705409 & 29.003142 & YANKEETOWN & 5 & 45 \\
\hline 65 & W-1240 & FGS & CUTTINGS & -82.758500 & 29.004470 & WITHLACOOCHEE BAY & 2 & 21 \\
\hline 66 & W-1242 & FGS & CUTTINGS & -82.878580 & 29.164720 & SUMNER & 2 & 12 \\
\hline 67 & W-1449 & FGS & CUTTINGS & -82.707650 & 29.351520 & BRONSON SW & 34 & 380 \\
\hline 68 & W-1841 & FGS & CUTTINGS & -82.551010 & 29.145030 & TIDEWATER & 81 & 600 \\
\hline 69 & W-1842 & FGS & CUTTINGS & -82.507950 & 29.062800 & YANKEETOWN SE & 71 & 1140 \\
\hline 70 & W-1843 & FGS & CUTTINGS & -82.757110 & 29.316420 & OTTER CREEK & 25 & 540 \\
\hline 71 & W-1846 & FGS & CUTTINGS & -82.976540 & 29.338650 & CHIEFLAND SW & 15 & 419 \\
\hline 72 & W-1847 & FGS & CUTTINGS & -82.551840 & 29.026140 & YANKEETOWN SE & 30 & 1198 \\
\hline 73 & W-1850 & FGS & CUTTINGS & -82.793850 & 29.313170 & OTTER CREEK & 26 & 600 \\
\hline 74 & W-2009 & FGS & CUTTINGS & -82.765870 & 29.320710 & OTTER CREEK & 26 & 205 \\
\hline 75 & W-2010 & FGS & CUTTINGS & -82.732940 & 29.291420 & BRONSON SW & 17 & 2173 \\
\hline 76 & W-2237 & FGS & CUTTINGS & -82.628220 & 29.438370 & BRONSON & 69 & 270 \\
\hline 77 & W-3052 & FGS & CUTTINGS & -82.819600 & 29.408650 & CHIEFLAND & 37 & 78 \\
\hline 78 & W-3342 & FGS & CUTTINGS & -82.746460 & 29.306450 & BRONSON SW & 26 & 3857 \\
\hline 79 & W-3556 & FGS & CUTTINGS & -82.977930 & 29.488650 & MANATEE SPRINGS & 10 & 102 \\
\hline 80 & W-6383 & FGS & CUTTINGS & -82.858210 & 29.494480 & CHIEFLAND & 29 & 310 \\
\hline 81 & W-7112 & FGS & CORE & -82.792940 & 29.208640 & WACCASASSA BAY & 3 & 57 \\
\hline 82 & W-7113 & FGS & CORE & -82.807660 & 29.201700 & WACCASASSA BAY & 4 & 57 \\
\hline 83 & W-7117 & FGS & CORE & -82.790720 & 29.243090 & WACCASASSA BAY & 7 & 50 \\
\hline 84 & W-7118 & FGS & CORE & -82.766280 & 29.239200 & WACCASASSA BAY & 5 & 50 \\
\hline 85 & W-7119 & FGS & CORE & -82.763260 & 29.236520 & WACCASASSA BAY & 5 & 28 \\
\hline 86 & W-7620 & FGS & CORE & -82.839050 & 29.216420 & WACCASASSA BAY & 5 & 55 \\
\hline 87 & W-7621 & FGS & CORE & -82.822110 & 29.210030 & WACCASASSA BAY & 10 & 55 \\
\hline 88 & W-7622 & FGS & CORE & -82.831550 & 29.203090 & WACCASASSA BAY & 6 & 60 \\
\hline 89 & W-7623 & FGS & CORE & -82.844610 & 29.220870 & WACCASASSA BAY & 6 & 42 \\
\hline 90 & W-7624 & FGS & CORE & -82.848470 & 29.217450 & WACCASASSA BAY & 8 & 55 \\
\hline 91 & W-7625 & FGS & CORE & -82.843080 & 29.218260 & WACCASASSA BAY & 9 & 55 \\
\hline 92 & W-7626 & FGS & CORE & -82.822280 & 29.213940 & WACCASASSA BAY & 10 & 55 \\
\hline 93 & W-7895 & FGS & CUTTINGS & -82.536840 & 29.097250 & YANKEETOWN SE & 36 & 32 \\
\hline 94 & W-7897 & FGS & CUTTINGS & -82.622120 & 29.026970 & YANKEETOWN SE & 32 & 64 \\
\hline 95 & W-7918 & FGS & CUTTINGS & -82.611560 & 29.021410 & YANKEETOWN SE & 30 & 67 \\
\hline 96 & W-9424 & FGS & CUTTINGS & -82.814050 & 29.292810 & OTTER CREEK & 21 & 670 \\
\hline 97 & W-9428 & FGS & CUTTINGS & -82.544340 & 29.148640 & TIDEWATER & 78 & 600 \\
\hline 98 & W-9433 & FGS & CUTTINGS & -82.797110 & 29.307260 & OTTER CREEK & 23 & 680 \\
\hline 99 & W-9434 & FGS & CUTTINGS & -82.644060 & 29.103920 & YANKEETOWN & 26 & 1235 \\
\hline 100 & W-9440 & FGS & CUTTINGS & -82.610450 & 29.089190 & YANKEETOWN SE & 49 & 475 \\
\hline 101 & W-9443 & FGS & CUTTINGS & -82.979880 & 29.336150 & CHIEFLAND SW & 14 & 410 \\
\hline 102 & W-9444 & FGS & CUTTINGS & -82.764050 & 29.234200 & WACCASASSA BAY & 14 & 380 \\
\hline 103 & W-9445 & FGS & CUTTINGS & -82.610170 & 29.060030 & YANKEETOWN SE & 46 & 420 \\
\hline 104 & W-9465 & FGS & CUTTINGS & -82.510450 & 29.060580 & YANKEETOWN SE & 62 & 1125 \\
\hline 105 & W-10850 & FGS & CUTTINGS & -82.565450 & 29.326420 & BRONSON SE & 83 & 198 \\
\hline 106 & W-12583 & FGS & CORE & -82.674430 & 29.026980 & YANKEETOWN & 13 & 12 \\
\hline 107 & W-13188 & FGS & CUTTINGS & -82.958490 & 29.494760 & MANATEE SPRINGS & 23 & 80 \\
\hline 108 & W-13374 & FGS & CUTTINGS & -82.880440 & 29.380310 & MANATEE SPRINGS & 30 & 50 \\
\hline 109 & W-13886 & FGS & CORE & -82.690170 & 29.040860 & YANKEETOWN & 10 & 306 \\
\hline 110 & W-13988 & FGS & CUTTINGS & -82.879880 & 29.321430 & CHIEFLAND SW & 28 & 30 \\
\hline 111 & W-14387 & FGS & CUTTINGS & -82.694430 & 29.044760 & YANKEETOWN & 11 & 315 \\
\hline 112 & W-15075 & FGS & CUTTINGS & -82.569620 & 29.129190 & TIDEWATER & 73 & 965 \\
\hline 113 & W-15077 & FGS & CUTTINGS & -82.569620 & 29.126420 & TIDEWATER & 67 & 780 \\
\hline 114 & W-16263 & FGS & CORE & -82.570830 & 29.128600 & TIDEWATER & 65 & 192 \\
\hline 115 & W-17351 & FGS & CUTTINGS & -82.648550 & 29.012460 & YANKEETOWN & 21 & 445 \\
\hline 116 & W-17470 & FGS & CORE & -82.557390 & 29.334200 & BRONSON SE & 72 & 53 \\
\hline 117 & W-17584 & FGS & CUTTINGS & -82.848210 & 29.463090 & CHIEFLAND & 35 & 320 \\
\hline 118 & W-17627 & FGS & CORE & -82.812940 & 29.178640 & WACCASASSA BAY & 1 & 2 \\
\hline 119 & W-17628 & FGS & CORE & -82.807110 & 29.169750 & WACCASASSA BAY & 1 & 2 \\
\hline
\end{tabular}




\section{FLORIDA GEOLOGICAL SURVEY}

\begin{tabular}{|c|c|c|c|c|c|c|c|c|}
\hline Map ID & Well Label & Data Source & Sample Type & Longitude & Latitude & 24K Quad & $\begin{array}{c}\text { Elevation } \\
(\mathrm{ft})\end{array}$ & $\begin{array}{c}\text { Total Depth } \\
\text { (ft) }\end{array}$ \\
\hline 120 & W-18436 & FGS & CORE & -82.979320 & 29.473100 & MANATEE SPRINGS & 11 & 40 \\
\hline 121 & W-18437 & FGS & CORE & -82.978760 & 29.485870 & MANATEE SPRINGS & 6 & 75 \\
\hline 122 & W-18460 & FGS & CORE & -82.973760 & 29.485870 & MANATEE SPRINGS & 14 & 80 \\
\hline 123 & W-18462 & FGS & CORE & -82.966820 & 29.484490 & MANATEE SPRINGS & 18 & 100 \\
\hline 124 & W-18602 & FGS & CORE & -82.557120 & 29.334200 & BRONSON SE & 72 & 64 \\
\hline 125 & W-19205 & FGS & CORE & -82.580000 & 29.198611 & TIDEWATER & 60 & 165 \\
\hline 126 & -111430017 & SRWMD & WATER WELL & -82.940275 & 29.489165 & MANATEE SPRINGS & 25 & - \\
\hline 127 & -111431001 & SRWMD & WATER WELL & -82.950275 & 29.483054 & MANATEE SPRINGS & 24 & - \\
\hline 128 & -111431006 & SRWMD & WATER WELL & -82.939553 & 29.478962 & MANATEE SPRINGS & 21 & - \\
\hline 129 & -111436012 & SRWMD & WATER WELL & -82.863886 & 29.484164 & CHIEFLAND & 35 & - \\
\hline 130 & -111526006 & SRWMD & WATER WELL & -82.774164 & 29.499720 & CHIEFLAND & 45 & - \\
\hline 131 & -111526008 & SRWMD & WATER WELL & -82.777775 & 29.493053 & CHIEFLAND & 52 & - \\
\hline 132 & -111529007 & SRWMD & WATER WELL & -82.828955 & 29.495148 & CHIEFLAND & 45 & - \\
\hline 133 & -111529009 & SRWMD & WATER WELL & -82.836664 & 29.493053 & CHIEFLAND & 44 & - \\
\hline 134 & -111530005 & SRWMD & WATER WELL & -82.999164 & 29.493887 & MANATEE SPRINGS & 40 & - \\
\hline 135 & -111531004 & SRWMD & WATER WELL & -82.839734 & 29.485805 & CHIEFLAND & 42 & - \\
\hline 136 & -111532006 & SRWMD & WATER WELL & -82.826684 & 29.480619 & CHIEFLAND & 44 & - \\
\hline 137 & -111533009 & SRWMD & WATER WELL & -82.814442 & 29.478331 & CHIEFLAND & 42 & - \\
\hline 138 & -111535004 & SRWMD & WATER WELL & -82.777454 & 29.483724 & CHIEFLAND & 50 & - \\
\hline 139 & -111535005 & SRWMD & WATER WELL & -82.779720 & 29.476109 & CHIEFLAND & 45 & - \\
\hline 140 & -111629001 & SRWMD & WATER WELL & -82.735831 & 29.492498 & BRONSON & 55 & - \\
\hline 141 & -111630002 & SRWMD & WATER WELL & -82.743886 & 29.496386 & BRONSON & 55 & - \\
\hline 142 & -111631002 & SRWMD & WATER WELL & -82.747061 & 29.475149 & BRONSON & 49 & - \\
\hline 143 & -111631003 & SRWMD & WATER WELL & -82.741109 & 29.477220 & BRONSON & 50 & - \\
\hline 144 & -111632005 & SRWMD & WATER WELL & -82.729164 & 29.488886 & BRONSON & 55 & - \\
\hline 145 & -111734001 & SRWMD & WATER WELL & -82.602775 & 29.492775 & BRONSON NE & 80 & - \\
\hline 146 & -111828002 & SRWMD & WATER WELL & -82.511387 & 29.495553 & BRONSON NE & 70 & - \\
\hline 147 & -111832001 & SRWMD & WATER WELL & -82.536942 & 29.484720 & BRONSON NE & 75 & - \\
\hline 148 & -121410004 & SRWMD & WATER WELL & -82.897497 & 29.452776 & MANATEE SPRINGS & 30 & - \\
\hline 149 & -121411010 & SRWMD & WATER WELL & -82.885275 & 29.448609 & MANATEE SPRINGS & 30 & - \\
\hline 150 & -121414002 & SRWMD & WATER WELL & -82.876386 & 29.436109 & MANATEE SPRINGS & 35 & - \\
\hline 151 & -121415005 & SRWMD & WATER WELL & -82.901942 & 29.444442 & MANATEE SPRINGS & 25 & - \\
\hline 152 & -121418004 & SRWMD & WATER WELL & -82.942497 & 29.436665 & MANATEE SPRINGS & 25 & - \\
\hline 153 & -121420001 & SRWMD & WATER WELL & -82.934164 & 29.418331 & MANATEE SPRINGS & 34 & - \\
\hline 154 & -121421005 & SRWMD & WATER WELL & -82.914132 & 29.422044 & MANATEE SPRINGS & 30 & - \\
\hline 155 & -121422004 & SRWMD & WATER WELL & -82.901664 & 29.427220 & MANATEE SPRINGS & 30 & - \\
\hline 156 & -121427002 & SRWMD & WATER WELL & -82.894164 & 29.415276 & MANATEE SPRINGS & 30 & - \\
\hline 157 & -121428003 & SRWMD & WATER WELL & -82.921664 & 29.402498 & MANATEE SPRINGS & 25 & - \\
\hline 158 & -121429005 & SRWMD & WATER WELL & -82.927628 & 29.415991 & MANATEE SPRINGS & 28 & - \\
\hline 159 & -121430002 & SRWMD & WATER WELL & -82.945830 & 29.404165 & MANATEE SPRINGS & 25 & - \\
\hline 160 & -121431002 & SRWMD & WATER WELL & -82.939164 & 29.393054 & MANATEE SPRINGS & 30 & - \\
\hline 161 & -121434002 & SRWMD & WATER WELL & -82.898053 & 29.387776 & MANATEE SPRINGS & 30 & - \\
\hline 162 & -121434003 & SRWMD & WATER WELL & -82.901108 & 29.398609 & MANATEE SPRINGS & 30 & - \\
\hline 163 & -121435003 & SRWMD & WATER WELL & -82.888331 & 29.391109 & MANATEE SPRINGS & 30 & - \\
\hline 164 & -121435007 & SRWMD & WATER WELL & -82.876386 & 29.391387 & MANATEE SPRINGS & 30 & - \\
\hline 165 & -121435008 & SRWMD & WATER WELL & -82.886764 & 29.398334 & MANATEE SPRINGS & 30 & - \\
\hline 166 & -121436002 & SRWMD & WATER WELL & -82.871164 & 29.398220 & CHIEFLAND & 32 & - \\
\hline 167 & -121501001 & SRWMD & WATER WELL & -82.757820 & 29.470722 & CHIEFLAND & 45 & - \\
\hline 168 & -121502002 & SRWMD & WATER WELL & -82.785553 & 29.467498 & CHIEFLAND & 40 & - \\
\hline 169 & -121503004 & SRWMD & WATER WELL & -82.800124 & 29.469568 & CHIEFLAND & 40 & - \\
\hline 170 & -121504003 & SRWMD & WATER WELL & -82.681109 & 29.463053 & BRONSON & 40 & - \\
\hline 171 & -121504004 & SRWMD & WATER WELL & -82.818609 & 29.465553 & CHIEFLAND & 40 & - \\
\hline 172 & -121505002 & SRWMD & WATER WELL & -82.839305 & 29.464045 & CHIEFLAND & 35 & - \\
\hline 173 & -121505004 & SRWMD & WATER WELL & -82.835944 & 29.473745 & CHIEFLAND & 40 & - \\
\hline 174 & -121505005 & SRWMD & WATER WELL & -82.831067 & 29.463956 & CHIEFLAND & 40 & - \\
\hline 175 & -121506001 & SRWMD & WATER WELL & -82.844330 & 29.472372 & CHIEFLAND & 35 & - \\
\hline 176 & -121507004 & SRWMD & WATER WELL & -82.838886 & 29.445553 & CHIEFLAND & 30 & - \\
\hline 177 & -121509003 & SRWMD & WATER WELL & -82.814442 & 29.459720 & CHIEFLAND & 38 & - \\
\hline 178 & -121517001 & SRWMD & WATER WELL & -82.832027 & 29.439430 & CHIEFLAND & 32 & - \\
\hline 179 & -121517002 & SRWMD & WATER WELL & -82.824691 & 29.441960 & CHIEFLAND & 32 & - \\
\hline 180 & -121704004 & SRWMD & WATER WELL & -82.620553 & 29.476387 & BRONSON NE & 91 & - \\
\hline
\end{tabular}


OPEN-FILE REPORT 94

\begin{tabular}{|c|c|c|c|c|c|c|c|c|}
\hline Map ID & Well Label & Data Source & Sample Type & Longitude & Latitude & 24K Quad & $\begin{array}{c}\text { Elevation } \\
(\mathrm{ft})\end{array}$ & $\begin{array}{c}\text { Total Depth } \\
\text { (ft) }\end{array}$ \\
\hline 181 & -121705001 & SRWMD & WATER WELL & -82.633081 & 29.463720 & BRONSON & 75 & - \\
\hline 182 & -121707001 & SRWMD & WATER WELL & -82.649442 & 29.451387 & BRONSON & 60 & - \\
\hline 183 & -121708001 & SRWMD & WATER WELL & -82.638886 & 29.454720 & BRONSON & 70 & - \\
\hline 184 & -121717003 & SRWMD & WATER WELL & -82.633664 & 29.446303 & BRONSON & 80 & - \\
\hline 185 & -121719002 & SRWMD & WATER WELL & -82.644164 & 29.428331 & BRONSON & 65 & - \\
\hline 186 & -121722002 & SRWMD & WATER WELL & -82.602775 & 29.428331 & BRONSON NE & 85 & - \\
\hline 187 & -121728002 & SRWMD & WATER WELL & -82.621386 & 29.407498 & BRONSON NE & 75 & - \\
\hline 188 & -121806001 & SRWMD & WATER WELL & -82.554720 & 29.473609 & BRONSON NE & 120 & - \\
\hline 189 & -131404002 & SRWMD & WATER WELL & -82.919997 & 29.379165 & MANATEE SPRINGS & 28 & - \\
\hline 190 & -131405001 & SRWMD & WATER WELL & -82.926612 & 29.376259 & MANATEE SPRINGS & 25 & - \\
\hline 191 & -131407002 & SRWMD & WATER WELL & -82.947219 & 29.371943 & CHIEFLAND SW & 25 & - \\
\hline 192 & -131410006 & SRWMD & WATER WELL & -82.898014 & 29.365813 & CHIEFLAND SW & 30 & - \\
\hline 193 & -131413001 & SRWMD & WATER WELL & -82.870553 & 29.357221 & OTTER CREEK & 30 & - \\
\hline 194 & -131509001 & SRWMD & WATER WELL & -82.816664 & 29.359998 & OTTER CREEK & 25 & - \\
\hline 195 & -131617003 & SRWMD & WATER WELL & -82.738886 & 29.351665 & BRONSON SW & 30 & - \\
\hline 196 & -131709001 & SRWMD & WATER WELL & -82.613053 & 29.369720 & BRONSON SE & 61 & - \\
\hline 197 & -131717001 & SRWMD & WATER WELL & -82.634386 & 29.347582 & BRONSON SW & 55 & - \\
\hline 198 & -131727003 & SRWMD & WATER WELL & -82.602497 & 29.328054 & BRONSON SE & 70 & - \\
\hline 199 & -131734003 & SRWMD & WATER WELL & -82.596664 & 29.306943 & BRONSON SE & 60 & - \\
\hline 200 & -141326001 & SRWMD & WATER WELL & -82.984441 & 29.231110 & SUMNER & 8 & - \\
\hline 201 & -141335001 & SRWMD & WATER WELL & -82.974719 & 29.212776 & SUMNER & 5 & - \\
\hline 202 & -141335007 & SRWMD & WATER WELL & -82.980274 & 29.215554 & SUMNER & 20 & - \\
\hline 203 & -141336003 & SRWMD & WATER WELL & -82.958608 & 29.223610 & SUMNER & 8 & - \\
\hline 204 & -141419001 & SRWMD & WATER WELL & -82.939719 & 29.249999 & SUMNER & 16 & - \\
\hline 205 & -141621002 & SRWMD & WATER WELL & -82.714720 & 29.259999 & BRONSON SW & 18 & - \\
\hline 206 & -141621003 & SRWMD & WATER WELL & -82.704997 & 29.251943 & BRONSON SW & 10 & - \\
\hline 207 & -141711001 & SRWMD & WATER WELL & -82.588330 & 29.286665 & BRONSON SE & 102 & - \\
\hline 208 & -141723003 & SRWMD & WATER WELL & -82.578886 & 29.251388 & BRONSON SE & 70 & - \\
\hline 209 & -151606001 & SRWMD & WATER WELL & -82.730831 & 29.211110 & LEBANON STATION & 7 & - \\
\hline 210 & -151703003 & SRWMD & WATER WELL & -82.577775 & 29.210276 & TIDEWATER & 80 & - \\
\hline 211 & -151719004 & SRWMD & WATER WELL & -82.630873 & 29.160195 & LEBANON STATION & 33 & - \\
\hline 212 & -171703001 & SRWMD & WATER WELL & -82.575276 & 29.036388 & YANKEETOWN SE & 30 & - \\
\hline 213 & 745306 & SWFWMD & WATER WELL & -82.560844 & 29.178194 & TIDEWATER & - & - \\
\hline 214 & 749003 & SWFWMD & WATER WELL & -82.568125 & 29.229206 & TIDEWATER & - & - \\
\hline 215 & 750182 & SWFWMD & WATER WELL & -82.572308 & 29.443286 & BRONSON NE & - & - \\
\hline 216 & 752296 & SWFWMD & WATER WELL & -82.543422 & 29.208856 & TIDEWATER & - & - \\
\hline 217 & 752578 & SWFWMD & WATER WELL & -82.542267 & 29.436556 & BRONSON NE & - & - \\
\hline 218 & 752802 & SWFWMD & WATER WELL & -82.514031 & 29.324158 & BRONSON SE & - & - \\
\hline 219 & 753034 & SWFWMD & WATER WELL & -82.538950 & 29.351936 & BRONSON SE & - & - \\
\hline 220 & 753382 & SWFWMD & WATER WELL & -82.530786 & 29.296864 & BRONSON SE & - & - \\
\hline 221 & 753427 & SWFWMD & WATER WELL & -82.653339 & 29.134439 & LEBANON STATION & - & - \\
\hline 222 & 753936 & SWFWMD & WATER WELL & -82.504408 & 29.169967 & TIDEWATER & - & - \\
\hline 223 & 754274 & SWFWMD & WATER WELL & -82.533806 & 29.420806 & BRONSON NE & - & - \\
\hline 224 & 754792 & SWFWMD & WATER WELL & -82.633386 & 29.081500 & YANKEETOWN & - & - \\
\hline 225 & 755360 & SWFWMD & WATER WELL & -82.583417 & 29.042833 & YANKEETOWN SE & - & - \\
\hline 226 & 755484 & SWFWMD & WATER WELL & -82.569689 & 29.407000 & BRONSON NE & - & - \\
\hline 227 & 755757 & SWFWMD & WATER WELL & -82.511869 & 29.139861 & TIDEWATER & - & - \\
\hline 228 & 756331 & SWFWMD & WATER WELL & -82.692183 & 29.008314 & YANKEETOWN & - & - \\
\hline 229 & 756382 & SWFWMD & WATER WELL & -82.688403 & 29.014650 & YANKEETOWN & - & - \\
\hline 230 & 756790 & SWFWMD & WATER WELL & -82.619667 & 29.447833 & BRONSON NE & - & - \\
\hline 231 & 757241 & SWFWMD & WATER WELL & -82.557892 & 29.289892 & BRONSON SE & - & - \\
\hline 232 & 757564 & SWFWMD & WATER WELL & -82.552861 & 29.413250 & BRONSON NE & - & - \\
\hline 233 & 757732 & SWFWMD & WATER WELL & -82.572889 & 29.358278 & BRONSON SE & - & - \\
\hline 234 & 757822 & SWFWMD & WATER WELL & -82.520944 & 29.360444 & BRONSON SE & - & - \\
\hline 235 & 757980 & SWFWMD & WATER WELL & -82.505778 & 29.287472 & BRONSON SE & - & - \\
\hline 236 & 758348 & SWFWMD & WATER WELL & -82.626631 & 29.064478 & YANKEETOWN & - & - \\
\hline 237 & 758476 & SWFWMD & WATER WELL & -82.522500 & 29.243222 & TIDEWATER & - & - \\
\hline 238 & 758558 & SWFWMD & WATER WELL & -82.522189 & 29.317308 & BRONSON SE & - & - \\
\hline 239 & 758625 & SWFWMD & WATER WELL & -82.636917 & 29.005111 & YANKEETOWN & - & - \\
\hline 240 & 759280 & SWFWMD & WATER WELL & -82.539194 & 29.396972 & BRONSON NE & - & - \\
\hline 241 & 760113 & SWFWMD & WATER WELL & -82.619833 & 29.456083 & BRONSON NE & - & - \\
\hline
\end{tabular}




\section{FLORIDA GEOLOGICAL SURVEY}

\begin{tabular}{|c|c|c|c|c|c|c|c|c|}
\hline Map ID & Well Label & Data Source & Sample Type & Longitude & Latitude & 24K Quad & $\begin{array}{c}\text { Elevation } \\
(\mathrm{ft})\end{array}$ & $\begin{array}{c}\text { Total Depth } \\
\text { (ft) }\end{array}$ \\
\hline 242 & 760253 & SWFWMD & WATER WELL & -82.527939 & 29.179842 & TIDEWATER & - & - \\
\hline 243 & 760736 & SWFWMD & WATER WELL & -82.588778 & 29.422194 & BRONSON NE & - & - \\
\hline 244 & 761360 & SWFWMD & WATER WELL & -82.611139 & 29.469000 & BRONSON NE & - & - \\
\hline 245 & 761477 & SWFWMD & WATER WELL & -82.559528 & 29.258139 & BRONSON SE & - & - \\
\hline 246 & 761481 & SWFWMD & WATER WELL & -82.538725 & 29.317636 & BRONSON SE & - & - \\
\hline 247 & 761557 & SWFWMD & WATER WELL & -82.567044 & 29.308278 & BRONSON SE & - & - \\
\hline 248 & 761751 & SWFWMD & WATER WELL & -82.525778 & 29.348722 & BRONSON SE & - & - \\
\hline 249 & 762133 & SWFWMD & WATER WELL & -82.580583 & 29.407472 & BRONSON NE & - & - \\
\hline 250 & 762313 & SWFWMD & WATER WELL & -82.532250 & 29.411222 & BRONSON NE & - & - \\
\hline 251 & 762464 & SWFWMD & WATER WELL & -82.573333 & 29.457833 & BRONSON NE & - & - \\
\hline 252 & 762512 & SWFWMD & WATER WELL & -82.706400 & 29.009144 & YANKEETOWN & - & - \\
\hline 253 & 762804 & SWFWMD & WATER WELL & -82.534500 & 29.325611 & BRONSON SE & - & - \\
\hline 254 & 763189 & SWFWMD & WATER WELL & -82.540694 & 29.266611 & BRONSON SE & - & - \\
\hline 255 & 763257 & SWFWMD & WATER WELL & -82.639806 & 29.116444 & YANKEETOWN & - & - \\
\hline 256 & 763383 & SWFWMD & WATER WELL & -82.608278 & 29.446722 & BRONSON NE & - & - \\
\hline 257 & 763775 & SWFWMD & WATER WELL & -82.564969 & 29.022219 & YANKEETOWN SE & - & - \\
\hline 258 & 763848 & SWFWMD & WATER WELL & -82.583611 & 29.493806 & BRONSON NE & - & - \\
\hline 259 & 763986 & SWFWMD & WATER WELL & -82.598417 & 29.456500 & BRONSON NE & - & - \\
\hline 260 & 764013 & SWFWMD & WATER WELL & -82.519972 & 29.401472 & BRONSON NE & - & - \\
\hline 261 & 764269 & SWFWMD & WATER WELL & -82.580639 & 29.374250 & BRONSON SE & - & - \\
\hline 262 & 764604 & SWFWMD & WATER WELL & -82.545861 & 29.254083 & BRONSON SE & - & - \\
\hline 263 & 764630 & SWFWMD & WATER WELL & -82.600361 & 29.445250 & BRONSON NE & - & - \\
\hline 264 & 765096 & SWFWMD & WATER WELL & -82.553889 & 29.347611 & BRONSON SE & - & - \\
\hline 265 & 765369 & SWFWMD & WATER WELL & -82.502817 & 29.215872 & TIDEWATER & - & - \\
\hline 266 & 765518 & SWFWMD & WATER WELL & -82.569739 & 29.018067 & YANKEETOWN SE & - & - \\
\hline 267 & 765570 & SWFWMD & WATER WELL & -82.553917 & 29.226833 & TIDEWATER & - & - \\
\hline 268 & 765689 & SWFWMD & WATER WELL & -82.516083 & 29.133419 & TIDEWATER & - & - \\
\hline 269 & 765798 & SWFWMD & WATER WELL & -82.555667 & 29.302778 & BRONSON SE & - & - \\
\hline 270 & 765853 & SWFWMD & WATER WELL & -82.501306 & 29.132956 & TIDEWATER & - & - \\
\hline 271 & 766331 & SWFWMD & WATER WELL & -82.540028 & 29.335694 & BRONSON SE & - & - \\
\hline 272 & 766402 & SWFWMD & WATER WELL & -82.579278 & 29.440556 & BRONSON NE & - & - \\
\hline 273 & 766425 & SWFWMD & WATER WELL & -82.527611 & 29.394583 & BRONSON NE & - & - \\
\hline 274 & 766468 & SWFWMD & WATER WELL & -82.696369 & 29.017511 & YANKEETOWN & - & - \\
\hline 275 & 766546 & SWFWMD & WATER WELL & -82.591444 & 29.472500 & BRONSON NE & - & - \\
\hline 276 & 766797 & SWFWMD & WATER WELL & -82.513306 & 29.360194 & BRONSON SE & - & - \\
\hline 277 & 766843 & SWFWMD & WATER WELL & -82.580472 & 29.456083 & BRONSON NE & - & - \\
\hline 278 & 766884 & SWFWMD & WATER WELL & -82.501775 & 29.049464 & YANKEETOWN SE & - & - \\
\hline 279 & 767545 & SWFWMD & WATER WELL & -82.559222 & 29.358500 & BRONSON SE & - & - \\
\hline 280 & 767772 & SWFWMD & WATER WELL & -82.556861 & 29.422694 & BRONSON NE & - & - \\
\hline 281 & 768087 & SWFWMD & WATER WELL & -82.505778 & 29.262083 & BRONSON SE & - & - \\
\hline 282 & 768359 & SWFWMD & WATER WELL & -82.522167 & 29.342278 & BRONSON SE & - & - \\
\hline 283 & 768825 & SWFWMD & WATER WELL & -82.656492 & 29.087525 & YANKEETOWN & - & - \\
\hline 284 & 769270 & SWFWMD & WATER WELL & -82.623556 & 29.119611 & YANKEETOWN SE & - & - \\
\hline 285 & 769468 & SWFWMD & WATER WELL & -82.584500 & 29.308194 & BRONSON SE & - & - \\
\hline 286 & 769499 & SWFWMD & WATER WELL & -82.538750 & 29.299528 & BRONSON SE & - & - \\
\hline 287 & 770012 & SWFWMD & WATER WELL & -82.511900 & 29.170531 & TIDEWATER & - & - \\
\hline 288 & 770354 & SWFWMD & WATER WELL & -82.545444 & 29.296472 & BRONSON SE & - & - \\
\hline 289 & 770796 & SWFWMD & WATER WELL & -82.582583 & 29.431222 & BRONSON NE & - & - \\
\hline 290 & 771067 & SWFWMD & WATER WELL & -82.592944 & 29.407639 & BRONSON NE & - & - \\
\hline 291 & 771165 & SWFWMD & WATER WELL & -82.603000 & 29.439556 & BRONSON NE & - & - \\
\hline 292 & 771444 & SWFWMD & WATER WELL & -82.590722 & 29.334222 & BRONSON SE & - & - \\
\hline 293 & 771511 & SWFWMD & WATER WELL & -82.605178 & 29.377931 & BRONSON NE & - & - \\
\hline 294 & 771576 & SWFWMD & WATER WELL & -82.582361 & 29.300556 & BRONSON SE & - & - \\
\hline 295 & 771578 & SWFWMD & WATER WELL & -82.563833 & 29.463306 & BRONSON NE & - & - \\
\hline 296 & 771598 & SWFWMD & WATER WELL & -82.578000 & 29.498139 & BRONSON NE & - & - \\
\hline 297 & 771706 & SWFWMD & WATER WELL & -82.560194 & 29.033139 & YANKEETOWN SE & - & - \\
\hline 298 & 771935 & SWFWMD & WATER WELL & -82.541444 & 29.415583 & BRONSON NE & - & - \\
\hline 299 & 772015 & SWFWMD & WATER WELL & -82.704358 & 29.036594 & YANKEETOWN & - & - \\
\hline 300 & 773513 & SWFWMD & WATER WELL & -82.520778 & 29.407583 & BRONSON NE & - & - \\
\hline 301 & 773537 & SWFWMD & WATER WELL & -82.500722 & 29.419778 & BRONSON NE & - & - \\
\hline 302 & 773714 & SWFWMD & WATER WELL & -82.569222 & 29.487389 & BRONSON NE & - & - \\
\hline
\end{tabular}


OPEN-FILE REPORT 94

\begin{tabular}{|c|c|c|c|c|c|c|c|c|}
\hline Map ID & Well Label & Data Source & Sample Type & Longitude & Latitude & 24K Quad & $\begin{array}{c}\text { Elevation } \\
(\mathrm{ft})\end{array}$ & $\begin{array}{c}\text { Total Depth } \\
\text { (ft) }\end{array}$ \\
\hline 303 & 773910 & SWFWMD & WATER WELL & -82.573944 & 29.424806 & BRONSON NE & - & - \\
\hline 304 & 774053 & SWFWMD & WATER WELL & -82.517806 & 29.434278 & BRONSON NE & - & - \\
\hline 305 & 774504 & SWFWMD & WATER WELL & -82.633028 & 29.107583 & YANKEETOWN & - & - \\
\hline 306 & 774559 & SWFWMD & WATER WELL & -82.586028 & 29.439028 & BRONSON NE & - & - \\
\hline 307 & 774569 & SWFWMD & WATER WELL & -82.542028 & 29.174083 & TIDEWATER & - & - \\
\hline 308 & 774611 & SWFWMD & WATER WELL & -82.538250 & 29.161056 & TIDEWATER & - & - \\
\hline 309 & 774972 & SWFWMD & WATER WELL & -82.512744 & 29.213056 & TIDEWATER & - & - \\
\hline 310 & 775019 & SWFWMD & WATER WELL & -82.609889 & 29.420139 & BRONSON NE & - & - \\
\hline 311 & 775152 & SWFWMD & WATER WELL & -82.652667 & 29.035389 & YANKEETOWN & - & - \\
\hline 312 & 775620 & SWFWMD & WATER WELL & -82.520806 & 29.154222 & TIDEWATER & - & - \\
\hline 313 & 776416 & SWFWMD & WATER WELL & -82.521833 & 29.291167 & BRONSON SE & - & - \\
\hline 314 & 776459 & SWFWMD & WATER WELL & -82.697306 & 29.028222 & YANKEETOWN & - & - \\
\hline 315 & 776884 & SWFWMD & WATER WELL & -82.596528 & 29.413194 & BRONSON NE & - & - \\
\hline 316 & 776900 & SWFWMD & WATER WELL & -82.590361 & 29.489778 & BRONSON NE & - & - \\
\hline 317 & 776993 & SWFWMD & WATER WELL & -82.613472 & 29.429028 & BRONSON NE & - & - \\
\hline 318 & 777053 & SWFWMD & WATER WELL & -82.590750 & 29.460889 & BRONSON NE & - & - \\
\hline 319 & 778006 & SWFWMD & WATER WELL & -82.511278 & 29.337528 & BRONSON SE & - & - \\
\hline 320 & 778351 & SWFWMD & WATER WELL & -82.500333 & 29.359250 & BRONSON SE & - & - \\
\hline 321 & 778357 & SWFWMD & WATER WELL & -82.520978 & 29.167583 & TIDEWATER & - & - \\
\hline 322 & 778957 & SWFWMD & WATER WELL & -82.622167 & 29.440000 & BRONSON NE & - & - \\
\hline 323 & 779397 & SWFWMD & WATER WELL & -82.532633 & 29.291436 & BRONSON SE & - & - \\
\hline 324 & 779475 & SWFWMD & WATER WELL & -82.568856 & 29.009517 & YANKEETOWN SE & - & - \\
\hline 325 & 780545 & SWFWMD & WATER WELL & -82.512833 & 29.346778 & BRONSON SE & - & - \\
\hline 326 & 780869 & SWFWMD & WATER WELL & -82.520278 & 29.265694 & BRONSON SE & - & - \\
\hline 327 & 781009 & SWFWMD & WATER WELL & -82.599750 & 29.465028 & BRONSON NE & - & - \\
\hline 328 & 781160 & SWFWMD & WATER WELL & -82.529917 & 29.236667 & TIDEWATER & - & - \\
\hline 329 & 781434 & SWFWMD & WATER WELL & -82.603589 & 29.048361 & YANKEETOWN SE & - & - \\
\hline 330 & 781739 & SWFWMD & WATER WELL & -82.538786 & 29.426714 & BRONSON NE & - & - \\
\hline 331 & 782113 & SWFWMD & WATER WELL & -82.547364 & 29.358478 & BRONSON SE & - & - \\
\hline 332 & 782129 & SWFWMD & WATER WELL & -82.593639 & 29.443194 & BRONSON NE & - & - \\
\hline 333 & 782185 & SWFWMD & WATER WELL & -82.535183 & 29.390061 & BRONSON NE & - & - \\
\hline 334 & 782402 & SWFWMD & WATER WELL & -82.541653 & 29.051800 & YANKEETOWN SE & - & - \\
\hline 335 & 782608 & SWFWMD & WATER WELL & -82.507028 & 29.360217 & BRONSON SE & - & - \\
\hline 336 & 782973 & SWFWMD & WATER WELL & -82.510839 & 29.446225 & BRONSON NE & - & - \\
\hline 337 & 783612 & SWFWMD & WATER WELL & -82.545028 & 29.192275 & TIDEWATER & - & - \\
\hline 338 & 784260 & SWFWMD & WATER WELL & -82.515936 & 29.443056 & BRONSON NE & - & - \\
\hline
\end{tabular}

NOTE: Suwannee River Water Management District (SRWMD) Well Label is the well's township, range, and section location. The format is as follows: + or - indicates township north (+) versus south (-); there is no need to include an east / west indicator for the range, as the entire SRWMD is east of the Prime Meridian. Following the $+/$ - are 6 digits representing the township, range, and section (TTRRSS), and finally a 3 digit unique identifier assigned consecutively to each well within a given section to differentiate wells with the same $+/$ - and 6 digit number.

For example: -031224004 means Township 03 South, Range 12 East, Section 24, unique well 004.

NOTE: Elevations for the Southwest Florida Water Management District (SWFWMD) wells used in this project were acquired from an FGS-generated Digital Elevation Model (DEM). 